\title{
Post-breakup burial and exhumation of the southern margin of Africa
}

\author{
Paul F. Green, ${ }^{*}$ Ian R. Duddy,* Peter Japsen, $\dagger$ Johan M. Bonow $\$, \S$ and Jean A. Malanף, ${ }^{1}$ \\ * Geotrack International Pty Ltd, West Brunswick, Vic., Australia \\ $\uparrow$ Geological Survey of Denmark and Greenland (GEUS), Copenhagen, Denmark \\ \$Mid Sweden University, Östersund, Sweden \\ $\S$ Södertörn University, Huddinge, Sweden \\ INew Age (African Global Energy) Ltd, London, UK
}

\begin{abstract}
Despite many years of study, the processes involved in the development of the continental margin of southern Africa and the distinctive topography of the hinterland remain poorly understood. Previous thermochronological studies carried out within a monotonic cooling framework have failed to take into account constraints provided by Mesozoic sedimentary basins along the southern margin. We report apatite fission track analysis and vitrinite reflectance data in outcrop samples from the Late Jurassic to Early Cretaceous sedimentary fill of the Oudtshoorn, Gamtoos and Algoa Basins (Uitenhage Group), as well as isolated sedimentary remnants further west, plus underlying Paleozoic rocks (Cape Supergroup) and Permian-Triassic sandstones from the Karoo Supergroup around the Great Escarpment. Results define a series of major regional cooling episodes. Latest Triassic to Early Jurassic cooling which began between 205 and $180 \mathrm{Ma}$ is seen dominantly in basement flanks to the Algoa and Gamtoos Basins. This episode may have affected a wider region but in most places any effects have been overprinted by later events. The effects of Early Cretaceous (beginning between 145 and $130 \mathrm{Ma}$ ) and Early to mid-Cretaceous (120-100 Ma) cooling are both delimited by major structures, while Late Cretaceous (85-75 Ma) cooling appears to have affected the whole region. These cooling events are all interpreted as dominantly reflecting exhumation. Higher Late Cretaceous paleotemperatures in samples from the core of the Swartberg Range, coupled with evidence for localised Cenozoic cooling, are interpreted as representing Cenozoic differential exhumation of the mountain range. Late Cretaceous paleotemperatures between $60^{\circ} \mathrm{C}$ and $90^{\circ} \mathrm{C}$ in outcropping Uitenhage Group sediments from the Oudtshoorn, Gamtoos and Algoa Basins require burial by between 1.2 and $2.2 \mathrm{~km}$ prior to Late Cretaceous exhumation. Because these sediments lie in depositional contact with underlying Paleozoic rocks in many places, relatively uniform Late Cretaceous paleotemperatures across most of the region, in samples of both basin fill and underlying basement, suggest the whole region may have been buried prior to Late Cretaceous exhumation. Cenozoic cooling (beginning between 30 and $20 \mathrm{Ma}$ ) is focussed mainly in mountainous regions and is interpreted as representing denudation which produced the modern-day relief. Features such as the Great Escarpment are not related to continental break up, as is often supposed, but are much younger (post-30 Ma). This history of post-breakup burial and subsequent episodic exhumation is very different from conventional ideas of passive margin evolution, and requires a radical re-think of models for development of continental margins.
\end{abstract}

\section{INTRODUCTION}

The distinctive elevation of southern Africa is well documented (e.g. King, 1951, 1967, 1972; Ollier \& Marker, 1985; de Wit, 2007). An inland region of low relief at elevations over $1 \mathrm{~km}$ above sea level (asl) and reaching

Correspondence: Paul F. Green, Geotrack International, 37 Melville Road, Brunswick West, Vic. 3055, Australia. E-mail: mail@geotrack.com.au.

${ }^{1}$ Present address: Getech Group PLC, Kitson House, Elmete Hall, Elmete Lane, Leeds, LS8 2LJ, UK up to $2 \mathrm{~km}$ asl or more in places (Fig. 1) is separated from low-lying areas towards the coast by a region of steep decline, forming part of what King (1951) referred to as the Great Escarpment running around southern Africa.

This landscape has been studied by a large number of authors over many years, using a variety of approaches (see reviews by Partridge \& Maud, 1987; Burke \& Gunnell, 2008), but despite many years of documentation and investigation there is little consensus regarding the evolution of this unusual present-day topography and the 
Fig. 1. Relief map highlighting the major landforms of central- and southern Africa (based on Amante \& Eakins, 2009).

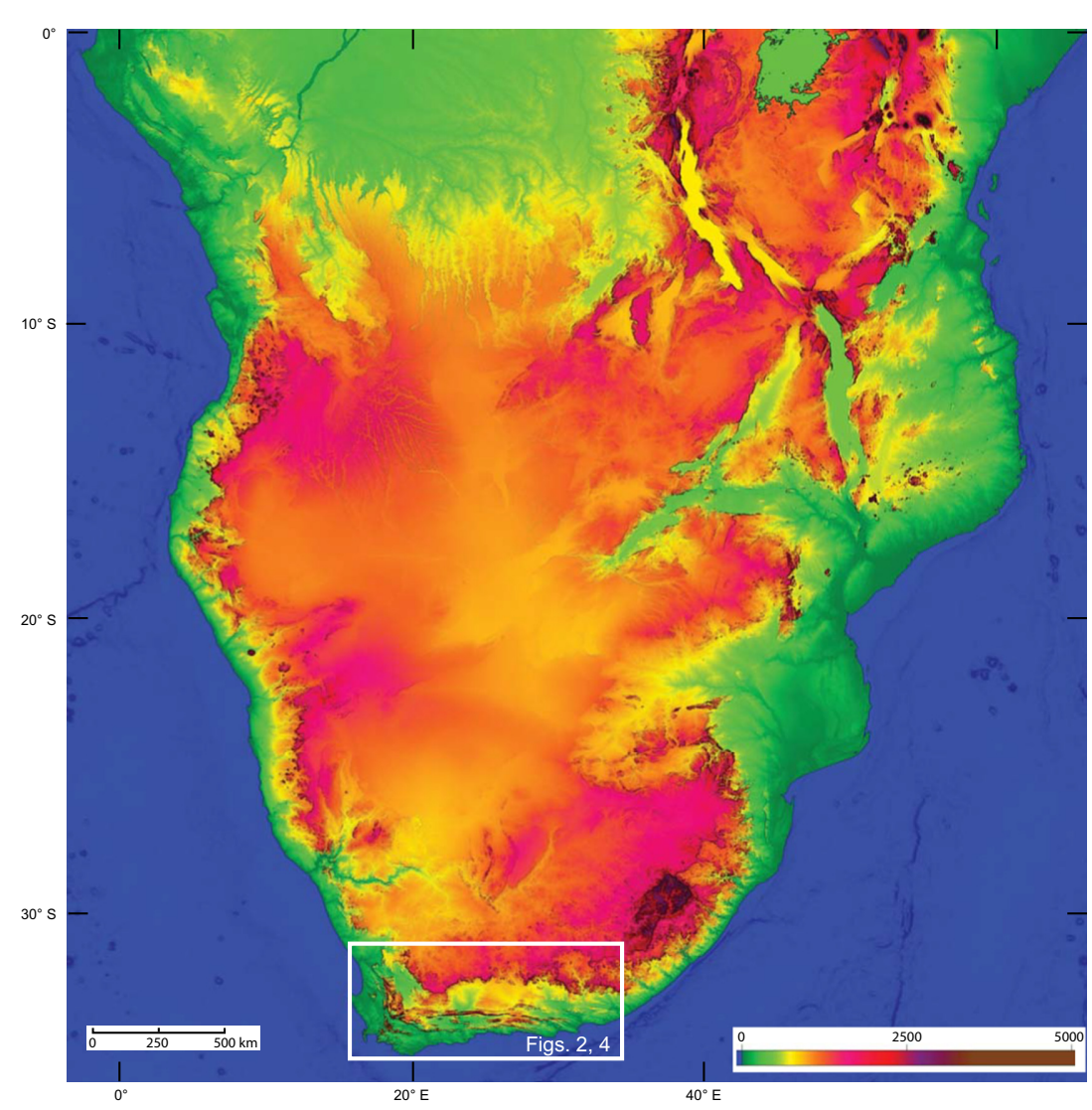

processes involved (Blenkinsop \& Moore, 2013). In particular, the time at which the plateau attained its presentday elevation is much-debated, with estimates ranging from Early Cretaceous or earlier to Pliocene. Conflicting ideas regarding the evolution of the landscape may, in part, reflect the diverse ways in which key geomorphological features of the region are described by different observers. Ollier \& Marker (1985) described the major geomorphic features of southern Africa as 'a plateau... bounded by the Great Escarpment and younger erosional features between the escarpment and the sea'. King $(1951,1967,1972)$ emphasised the 'stepped' nature of the landscape and the presence of planation surfaces at different levels within the elevated region, rather than a single plateau surface. Moore et al. (2009) emphasised the presence of three distinct drainage divides forming a 'horseshoe-shaped' pattern across southern Africa. Differing descriptions and emphases inevitably lead to different interpretations of landscape evolution.

In recent years, low temperature thermochronology studies have documented widespread Cretaceous denudation across southern Africa (Brown et al., 1990, 1998, 2002, 2014; Gallagher \& Brown, 1999a,b; Raab et al., 2002, 2005; Kounov et al., 2008, 2009, 2013; Tinker et al., 2008a; Stanley et al., 2013). But despite consistent evidence of major Cretaceous cooling over a wide region, interpreted predominantly in terms of exhumation, key aspects such as the precise timing and amount of exhumation and how this relates to the uplift of the present-day plateau are far from settled (e.g. Burke \& Gunnell, 2008; Paton, 2012).

One reason why this has proven so problematical is the lack of post-Jurassic stratigraphic reference points over much of the region, while where such constraints are present, previous thermochronological studies have failed to take them into account (Green et al., 2013).

Here, we report new apatite fission track analysis $\left(\mathrm{AFTA}^{\circledR}{ }^{\circledR 1}\right.$ ) data and vitrinite reflectance (VR) data from the hitherto largely ignored (as regards thermochronology) extensional Late Jurassic to Early Cretaceous basins along the southern margin of Africa, plus older rocks in adjacent regions (Fig. 2). The results define a very different style of evolution to previously accepted ideas regarding the development of elevated passive continental margins (EPCMs; Japsen et al., 2012a) in general, and southern Africa in particular (Burke \& Gunnell, 2008; Tinker et al., 2008a,b; Braun et al., 2014), with major implications for the nature of the underlying tectonic processes, as well as for hydrocarbon exploration in offshore basins.

\section{GEOLOGICAL SETTING}

The geology of the study area (Fig. 2) is described in Johnson et al. (2009), while the Paleozoic to Early Jurassic

${ }^{1}$ AFTA is the registered trademark of Geotrack International Pty Ltd. 


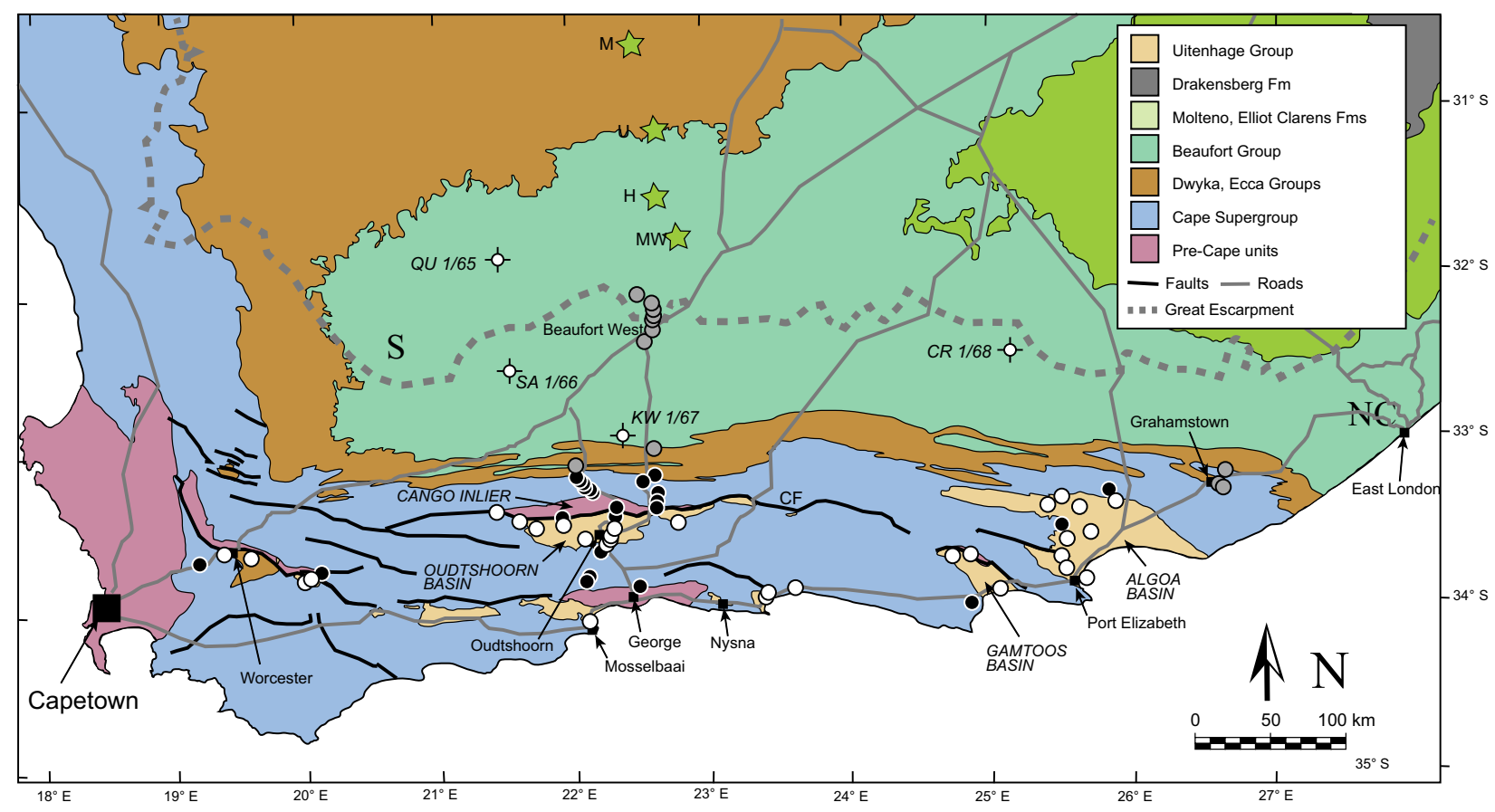

Fig. 2. Map showing basic geology plus locations of samples analysed for this study. Open symbols represent samples of Mesozoic sedimentary rocks. Black symbols with white outlines represent samples of Paleozoic rocks. Grey fill denotes samples from the Karoo Supergroup. Four kimberlites studied by Stanley et al. (2013) are denoted by stars; M; Markt. U; Uintjiesberg. H; Hebron. MW; Melton Wold. CF: Cango Fault. S: Sutherland. NC: Needs Camp. W: Worcester. Four boreholes from which Tinker et al. (2008a) reported results are also shown.

tectonic development of the region is reviewed by Tankard et al. (2009). The region is dominated by the Permian to Early Jurassic Karoo Basin in the north and the Paleozoic Cape Foldbelt to the south, into which Late Jurassic to Early Cretaceous extensional basins related to breakup of the southern margin developed along reactivated Paleozoic compressional structures within the Cape Foldbelt (Bate \& Malan, 1992; Paton \& Underhill, 2004). Catuneanu et al. (2005) describe the Karoo sequence over a wider region of southern Africa.

Basic stratigraphy of the study region is summarised in Fig. 3. The Cape Foldbelt is dominated by rocks of the Cape Supergroup (Cambrian to Early Carboniferous) while older rocks (pre-Cape) occur to the north of Oudtshoorn (Cango inlier), around George (Kaaimans inlier), on the northern flank of the Gamtoos Basin (Gamtoos inlier) and over a wider area in the west around Cape Town (Fig. 2). A prominent hiatus representing the interval ca. 330-302 Ma separates the Cape Supergroup from the Permian to Early Jurassic Karoo Supergroup (Fig. 3). Development of the Cape Foldbelt is conventionally dated to the interval $278-230 \mathrm{Ma}$ (Newton et al., 2009) but Tankard et al. (2009) suggest that initiation is better represented by a hiatus within the Beaufort Group of the Karoo Supergroup at $c a .250 \mathrm{Ma}$, with tectonism extending to $215 \mathrm{Ma}$. The Karoo sequence is terminated by the Middle Jurassic continental flood basalts of the Drakensberg volcanics and extensive associated intrusive activity. While earlier dating studies suggested a somewhat protracted timescale for eruption of lavas, with ages between $c a .175$ and $184 \mathrm{Ma}$ (Duncan et al., 1997; Jourdan et al., 2005), more recent studies suggest sill emplacement in less than one million years, at $c a .183 \mathrm{Ma}$ (Svensen et al., 2012).

The oldest unit of the post-Karoo sequence is the dominantly volcanic Suurberg Group (Hill, 1992), of which the youngest unit (Mimosa Formation) has been dated at ca. $160 \mathrm{Ma}$ (Dingle et al., 1983). The main fill of the extensional basin system is the Late Jurassic to Early Cretaceous Uitenhage Group, comprising the Enon Conglomerate, Kirkwood Sandstone and Sundays River Formations, now preserved onshore in a number of separate basins and scattered outcrops stretching from close to Cape Town in the west to Port Elizabeth in the east (Dingle et al., 1983; Shone, 2009). No younger sedimentary units are preserved in the onshore basins. However, the basin system is more extensively developed offshore where a range of younger units and numerous intervening unconformities have been recorded, with the whole system known as the Outeniqua Basin (e.g. Broad et al., 2009). The precise age of the Uitenhage Group remains uncertain due to lack of diagnostic fossils. For this study we have adopted a Tithonian to Valanginian age (151$136 \mathrm{Ma})$, based on information in Dingle et al. (1983) and Shone (2009).

Kimberlites of various ages from Precambrian to Late Cretaceous are widespread across the region (Jelsma et al., 2004, 2009), some of which show clear evidence of 
Fig. 3. Summary stratigraphic column for the southern margin of Africa, based mainly on information in Tankard et al. (2009) and Johnson et al. (2009). Cooling events identified from AFTA in this study are also shown. Cooling events listed in Table 1 are linked to the events shown here by colour.

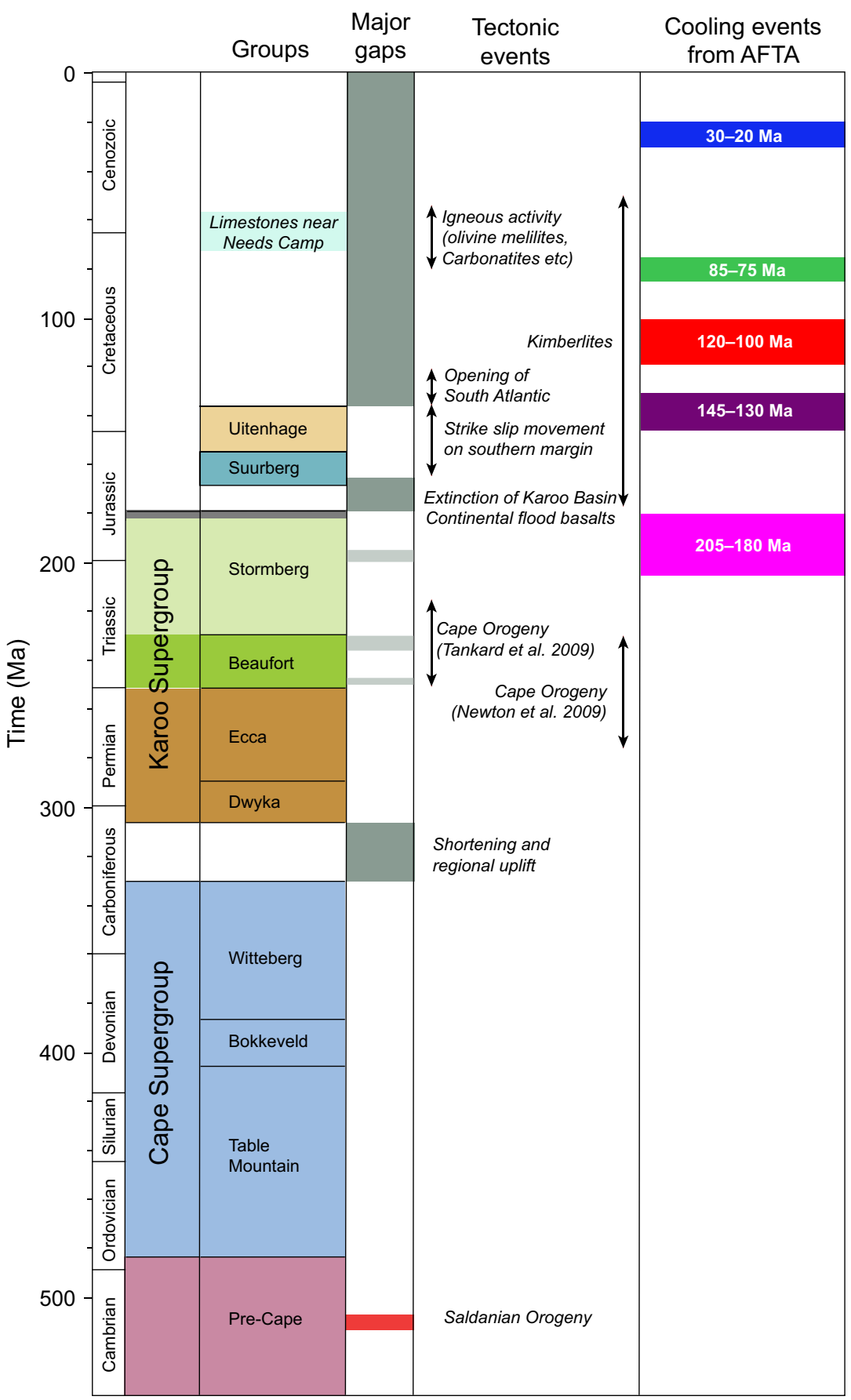

preservation of Upper Cretaceous surface deposits (e.g. Smith, 1986), while Upper Cretaceous and Cenozoic igneous rocks also occur, e.g. around Sutherland (Fig. 2) and elsewhere (Moore et al., 2008). Around Grahamstown, a prominent planation surface associated with kaolinitic weathering is attributed a Late Cretaceous age (Lewis, 1995). Further east, around Needs Camp (Fig. 2) and other locations, Maastrichtian and Eocene limestones rest on a marine erosional surface which cuts across underlying Early Cretaceous units of the Sundays River Formation (Uitenhage Group) and older units (Lewis, 1995; Roberts et al., 2009; Shone, 2009).

The general large-scale landscape features in the study area consist of a coastal plain, several mountain ranges parallel to the coast and vast plains separated by distinct escarpments (Fig. 4). The coastal platform in the south around George is an elevated planation surface at 180$280 \mathrm{~m}$ asl, with an abrupt decline to sea level at the coast (Roberts et al., 2008). This is bounded to the north by narrow west-east trending mountain ranges, the Langeberg and Swartberg, with highest summits in the Swartberg Range around $2 \mathrm{~km}$ asl. The Langeberg in the south and Swartberg in the north, bound the Oudtshoorn Basin. North of Swartberg the Great Karoo plain (600$800 \mathrm{~m}$ asl) extends northwards for $100 \mathrm{~km}$ and for more than $300 \mathrm{~km}$ in the west-east direction. The almost featureless plain ends in the north around Beaufort West at an abrupt escarpment above which the interior plain of 


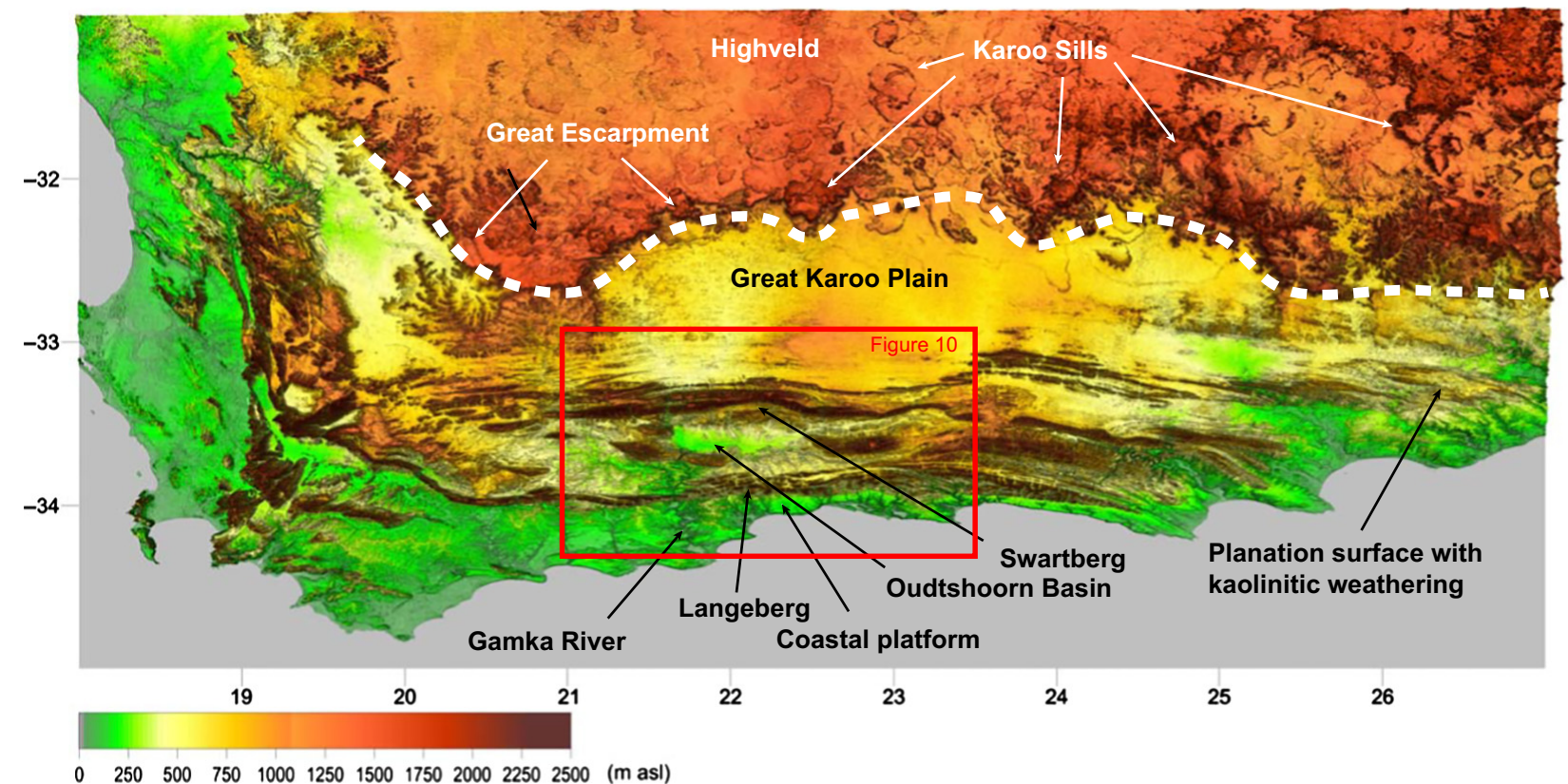

Fig. 4. Relief map of the southern margin of the African continent, highlighting the main landscape elements of the study area. Location shown in Fig. 1. The drainage pattern of the major rivers mainly follows the west-east mountain ranges, but occasionally rivers break through southwards towards the ocean, forming spectacular canyons with depths of a kilometre or more. The rivers along the flanks of the Oudtshoorn Basin show internal drainage. The western Karoo plain is drained by only one major river (Gamka) heading south. This river has broken through both the Langeberg and Swartberg ranges and also drains the Oudtshoorn Basin, with both inlet and outlet for the river in the western part of the basin. The eastern Karoo plain is less affected by southerly drainage, but instead has its major outlets towards the east-southeast.

the Highveld reaches heights of $1500 \mathrm{~m}$ asl or above, declining gently further north. The escarpment is largely controlled by abundant Jurassic dolerite sills, producing the staircase or stepped nature of the landscape in this region.

\section{NEW AFTA AND VR DATA IN LATE JURASSIC-EARLY CRETACEOUS RIFT BASINS AND OLDER ROCKS OF THE SOUTHERN CAPE}

\section{Sample details and analytical methods}

For this study, AFTA and VR data were obtained in outcrop samples of sedimentary rocks from the Late Jurassic to Early Cretaceous extensional basins, including the Oudtshoorn, Gamtoos and Algoa Basins, as well as isolated sedimentary remnants of similar age further west around Worcester (Fig. 2). Samples for AFTA were taken of sandstones from the Enon, Kirkwood and Sundays River formations of the Uitenhage Group, and quartzites from the underlying Cape Supergroup and older units. Samples for VR were taken from fine grained carbonaceous units and coaly material from sandstones of the Kirkwood and Sundays River Fms. Additional samples for AFTA were collected from outcrops of Karoo Supergroup units extending from the northern side of the Swartberg range to above the Great Escarpment north of Beaufort West, in a roughly north-south transect covering similar ground to Tinker et al. (2008a). In presenting and discussing data below, we refer to all pre-Karoo samples as 'basement', for simplicity.

Details of all AFTA samples are listed in Table 1, together with summary AFTA parameters and corresponding thermal history interpretations, while details of VR samples are listed in Table 2 together with summary data. Full details of both AFTA and VR data, plus analytical details, are provided in an online supplementary data file. Locations of all samples are shown in Fig. 5, where they are divided into geographical regions for discussion purposes.

\section{AFTA and VR results}

Mean confined track lengths are plotted against apatite fission track (AFT) age in Fig. 6, together with data from previous studies in the region (outcrop samples only). The new and published datasets define a broadly consistent trend, with samples giving the youngest fission track ages around 80-100 Ma tending to show the longest mean lengths around $14 \mu \mathrm{m}$, while in samples with ages around $150 \mathrm{Ma}$ mean track lengths are lower, around $13 \mu \mathrm{m}$. Mean track length increases slightly to $c a .13 .5 \mu \mathrm{m}$ in samples giving the oldest ages between 170 and $230 \mathrm{Ma}$. These oldest ages, which are only present in the new data and are not represented in the published datasets, were measured predominantly in samples from the Algoa and Gamtoos Basins (both Uitenhage Group sedimentary 
units and basement) in the east of the study region. In contrast, ages in samples of Uitenhage Group sediments across the western and central parts of the region span almost the entire range of measured ages, with youngest values around $100 \mathrm{Ma}$ or slightly younger. Basement samples show a progressive decrease in AFT age from east to west, with values around $180 \mathrm{Ma}$ at eastern locations around the Algoa and Gamtoos Basins, between 100 and $150 \mathrm{Ma}$ in central locations around the Oudtshoorn Basin and around $100 \mathrm{Ma}$ at westerly locations around Worcester. Many of the youngest ages, between 80 and $100 \mathrm{Ma}$, were measured in samples of Karoo Supergroup around Beaufort West, similar to results from Tinker et al. (2008a). Given the consistency between new and published data in Fig. 6 (although the two datasets diverge somewhat towards older ages), we consider it reasonable to extend conclusions regarding the thermal history of samples from this study to the published data in samples across the wider region.

At first sight, the data in Fig. 6 could be considered as defining a classic 'boomerang trend' as defined by Green (1986), representing the progressive overprinting of an older component of tracks by heating in a single dominant paleo-thermal event. However, quantitative thermal history constraints derived from the AFTA data define a more complex variation in thermal history across the region, as explained in detail below.

Apatite fission track ages in many of the samples of Uitenhage Group sandstones from western and central locations are significantly younger than the 151$136 \mathrm{Ma}$ depositional age of the Uitenhage Group sedimentary units, showing that these samples must have been significantly hotter than their present-day surface temperatures at some time after deposition of these units. Other Uitenhage Group samples have not been heated sufficiently to reduce fission track ages significantly below the depositional age of the Uitenhage Group, but the track length data, with mean track lengths generally around $13.5 \mu \mathrm{m}$, show a greater degree of length reduction than can be accounted for by prolonged surface (or near-surface) exposure, showing that these samples have also been hotter than they are today at some time since deposition.

Mean VR values in samples from the Algoa and Gamtoos Basins (Table 2) are generally uniform across the region, with most values in the range $0.4-0.54 \%$. Only small numbers of measurements were possible in many samples, probably due to the degree of weathering of the organic matter, and only one sample provided an analysis of the highest reliability, based on measurement of 25 separate fields of vitrinite. But duplicate values in samples from the same locality are consistent (Table 2), and measured values around $0.4-0.5 \%$, indicating maximum paleotemperatures of $60-80^{\circ} \mathrm{C}$, are consistent with interpretations derived from AFTA data in adjacent samples (below). Therefore, the measured VR values are regarded as providing a reliable indication of the thermal history of the sampled units.

\section{Thermal history constraints from AFTA and VR in this study}

The approach that we take in extracting thermal history information from fission tracks in apatite differs in several respects from that taken by many other workers (see Green et al., 2013 for an explanation of different approaches). Rather than attempting to define the entire thermal history within a monotonic cooling framework, as is common in many studies, for reasons explained by Green \& Duddy (2012) and Green et al. (2013) we parameterise the thermal history in very simple fashion, defining only those key aspects of the thermal history which control the measured parameters. For sedimentary rocks these are the maximum post-depositional paleotemperature and the time at which cooling from the paleo-thermal maximum began. One or two additional subsequent events may also be defined if required by the data. For basement samples as well as for sandstones which have been sufficiently heated after deposition, we define the time at which each sample cooled below $c a .110^{\circ} \mathrm{C}$ and began to retain tracks (the actual paleotemperature depending on the distribution of $\mathrm{Cl}$ contents in each sample), together with the magnitude of the peak paleotemperatures in one or two subsequent heating and cooling events. In this study, where basement samples are directly overlain by Late Jurassic to Early Cretaceous Uitenhage Group sediments, scenarios involving episodic heating and cooling are clearly appropriate, while experience in a wide variety of different settings (Green et al., 2013) leads us to conclude that this style of thermal history is generally more appropriate than slow monotonic cooling.

By comparing the fission track age and track length distribution predicted from a range of candidate paleo-thermal scenarios with measured parameters, the range of conditions (maximum/peak paleotemperature and onset of cooling) giving predictions that are consistent with the measured data within $95 \%$ confidence limits can be defined. In practise the variation in fission track age and track length distribution with wt $\%$ $\mathrm{Cl}$ is used to define the range of viable solutions, as illustrated in detail by Green \& Duddy (2010, 2012) and Green et al. (2013). Beginning with a 'default thermal history' (Green \& Duddy, 2012) consisting of prolonged residence at surface temperature for outcrop samples, candidate thermal histories are created by adding one or more episodes of heating and cooling (at assumed rates of $1^{\circ} \mathrm{C} \mathrm{Myr}^{-1}$ and $10^{\circ} \mathrm{C} \mathrm{Myr}^{-1}$, respectively), also including a predepositional episode in the case of sedimentary rock samples (although we focus on post-depositional heating here). For predicting expected AFTA parameters, we use an in-house model of fission-track annealing kinetics which takes full quantitative allowance of the influence of $\mathrm{wt} \% \mathrm{Cl}$ on annealing rates. The variation in annealing kinetics with $\mathrm{wt} \% \mathrm{Cl}$ embodied in this model is very similar to that displayed in the data of Carlson et al. (1999) and Barbarand et al. 
Table 1. AFTA data, sample details and associated thermal history interpretations; South African margin

\begin{tabular}{|c|c|c|c|c|c|}
\hline $\begin{array}{l}\text { Sample } \\
\text { number }\end{array}$ & Lat/long & Stratigraphic unit $\dagger$ & Stratigraphic division & $\begin{array}{l}\text { Stratigraphic } \\
\text { age } \uparrow(\mathrm{Ma})\end{array}$ & $\begin{array}{l}\text { Elevation } \\
\text { (m asl) }\end{array}$ \\
\hline GC1070-1 & $-33.6995 / 19.2088$ & Table Mtn Group & Ordovician & $488-444$ & 375 \\
\hline GC1070-2 & $-33.6353 / 19.3873$ & Enon Enon Conglomerate & Tithonian - Valanginian & $151-136$ & 232 \\
\hline GC1070-3 & $-33.6906 / 19.5915$ & Enon Enon Conglomerate & Tithonian - Valanginian & $151-136$ & 289 \\
\hline GC1070-4 & $-33.8288 / 20.0645$ & Enon Enon Conglomerate & Tithonian - Valanginian & $151-136$ & 174 \\
\hline GC1070-5 & $-33.8029 / 20.0953$ & Table Mtn Group & Ordovician & $488-444$ & 209 \\
\hline GC1070-6 & $-33.8349 / 20.0009$ & Enon Conglomerate & Tithonian - Valanginian & $151-136$ & 188 \\
\hline GC1070-7 & $-33.4153 / 21.4038$ & Table Mtn Group & Ordovician & $488-444$ & 796 \\
\hline GC1070-8 & $-33.4886 / 21.5700$ & Pre-Cape (Kansa Grp) & Cambrian-E. Ordovician? & $510-480$ & 509 \\
\hline GC1070-9 & $-33.4976 / 21.8763$ & Pre-Cape (Kansa Grp) & Cambrian-E. Ordovician? & $510-480$ & 426 \\
\hline GC1070-10 & $-33.5020 / 21.8780$ & Buffleskloof Fm & Tithonian - Valanginian & $151-136$ & 413 \\
\hline GC1070-11 & $-33.5963 / 22.0306$ & Kirkwood sst & Tithonian - Valanginian & $151-136$ & 287 \\
\hline GC1070-12 & $-33.5780 / 22.2077$ & Enon Enon Conglomerate & Tithonian - Valanginian & $151-136$ & 306 \\
\hline GC1070-13 & $-33.6452 / 22.1970$ & Enon & Tithonian - Valanginian & $151-136$ & 343 \\
\hline GC1070-14 & $-33.5780 / 22.2077$ & Kirkwood sst & Tithonian - Valanginian & $151-136$ & 384 \\
\hline GC1070-15 & $-33.5352 / 22.2447$ & Pre-Cape (Kansa Grp) & Cambrian-E. Ordovician? & $510-480$ & 498 \\
\hline GC1070-16 & $-33.4489 / 22.2534$ & Kirkwood sst & Tithonian - Valanginian & $151-136$ & 479 \\
\hline GC1070-17 & $-33.5011 / 22.6887$ & Kirkwood sst & Tithonian - Valanginian & $151-136$ & 259 \\
\hline GC1070-18 & $-33.22670 / 26.6347$ & Dwyka Tillite & L. Carb-E. Permian & $305-290$ & 586 \\
\hline GC1070-19 & $-33.3075 / 26.5762$ & Dwyka Tillite & L. Carb-E. Permian & $305-290$ & 586 \\
\hline GC1070-20 & $-33.3327 / 26.608$ & Witteberg Gp & L Devonian-ECarboniferous & $385-330$ & 650 \\
\hline GC1070-21 & $-33.9525 / 23.5729$ & Uitenhage Grp? & Tithonian - Valanginian & $151-136$ & 241 \\
\hline GC1070-22 & $-34.0041 / 23.4256$ & Enon Conglomerate & Tithonian - Valanginian & $151-136$ & 81 \\
\hline GC1070-23 & $-34.0041 / 23.4256$ & Enon Conglomerate & Tithonian - Valanginian & $151-136$ & 81 \\
\hline GC1070-24 & $-33.9064 / 22.4063$ & Table Mtn Group & Ordovician-Silurian & $486-416$ & 607 \\
\hline GC1070-25 & $33.421 / 22.2411$ & Pre-Cape (Kansa Grp) & Cambrian-E. Ordovician? & $510-480$ & 528 \\
\hline GC1070-26 & $-33.3659 / 22.0938$ & Table Mtn Group & Ordovician-Silurian & $486-416$ & 1050 \\
\hline GC1070-27 & $-33.3636 / 22.0656$ & Table Mtn Group & Ordovician-Silurian & $486-416$ & 1235 \\
\hline GC1070-28 & $-33.3586 / 22.0543$ & Table Mtn Group & Ordovician-Silurian & $486-416$ & 1412 \\
\hline GC1070-29 & $-33.3521 / 22.0474$ & Table Mtn Group & Ordovician-Silurian & $486-416$ & 1575 \\
\hline GC1070-30 & $-33.3288 / 22.043$ & Table Mtn Group & Ordovician-Silurian & $486-416$ & 1414 \\
\hline GC1070-31 & $-33.2951 / 22.0522$ & Table Mtn Group & Ordovician-Silurian & $486-416$ & 797 \\
\hline GC1070-32 & $-33.1475 / 21.963$ & Ecca Group & Permian & $290-250$ & 516 \\
\hline GC1070-33 & $-32.3090 / 22.5719$ & Beaufort Group & Early-Middle Triassic & $250-230$ & 891 \\
\hline GC1070-34 & $-32.2631 / 22.5663$ & Beaufort Group & Early-Middle Triassic & $250-230$ & 1038 \\
\hline GC1070-35 & $-32.2571 / 22.5712$ & Karoo Sill & Early Jurassic & 180 & 1088 \\
\hline GC1070-36 & $-32.2129 / 22.5579$ & Beaufort Group & Early-Middle Triassic & $250-230$ & 1262 \\
\hline
\end{tabular}




\begin{tabular}{|c|c|c|c|c|c|c|c|}
\hline $\begin{array}{l}\rho_{\mathrm{D}} \\
\left(10^{6} \text { tracks }\right. \\
\left.\mathrm{cm}^{-2}\right)\end{array}$ & $\begin{array}{l}\rho_{\mathrm{s}}^{\dagger} \\
(106 \text { tracks } \\
\left.\mathrm{cm}^{-2}\right)\end{array}$ & $\begin{array}{l}\rho_{\mathrm{i}}^{\dagger} \\
\left(10^{6} \text { tracks }\right. \\
\left.\mathrm{cm}^{-2}\right)\end{array}$ & $\begin{array}{l}P\left(\chi^{2}\right) \S(\%) \\
\text { (no. of grains) }\end{array}$ & $\begin{array}{l}\text { Fission track } \\
\text { age }(\mathrm{Ma})\end{array}$ & $\begin{array}{l}\text { Mean track } \\
\text { length } \|(\mu \mathrm{m})\end{array}$ & $\begin{array}{l}\text { Std } \\
\text { dev** } \\
(\mu \mathrm{m})\end{array}$ & $\begin{array}{l}\text { Thermal history } \\
\text { constraints } \dagger \dagger\end{array}$ \\
\hline $1.300(2079)$ & $1.329(271)$ & $3.978(811)$ & $<1(19)$ & $82.3 \pm 9.1^{*}$ & $13.7 \pm 0.3(35)$ & 1.51 & $\begin{array}{l}>125^{\circ} \mathrm{C} ;>80 \mathrm{Ma} \\
70-120^{\circ} \mathrm{C}, 95-45 \mathrm{Ma} \\
20-75^{\circ} \mathrm{C}, 65-0 \mathrm{Ma}\end{array}$ \\
\hline $1.303(2079)$ & $0.832(381)$ & $2.135(978)$ & $4(20)$ & $95.4 \pm 8.5^{*}$ & $13.2 \pm 0.2(105)$ & 1.89 & $\begin{array}{l}>125^{\circ} \mathrm{C}, 140-100 \mathrm{Ma} \\
85-100^{\circ} \mathrm{C}, 105-70 \mathrm{Ma} \\
45-65^{\circ} \mathrm{C}, 45-0 \mathrm{Ma}\end{array}$ \\
\hline $1.306(2079)$ & $0.877(355)$ & $1.651(668)$ & $11(20)$ & $134.9 \pm 9.7$ & $13.6 \pm 0.2(108)$ & 2.03 & $\begin{array}{l}95-130^{\circ} \mathrm{C}, 160-80 \mathrm{Ma} \\
65-90^{\circ} \mathrm{C}, 105-50 \mathrm{Ma}\end{array}$ \\
\hline $1.308(2079)$ & $0.833(493)$ & $1.619(958)$ & $<1(19)$ & $130.1 \pm 14.0^{*}$ & $12.8 \pm 0.2(104)$ & 2.16 & $\begin{array}{l}80-110^{\circ} \mathrm{C} ; 140-75 \mathrm{Ma} \\
50-75^{\circ} \mathrm{C} ; 65-0 \mathrm{Ma}\end{array}$ \\
\hline $1.311(2079)$ & $0.999(342)$ & $2.395(820)$ & $87(20)$ & $106.5 \pm 7.5$ & $13.3 \pm 0.2(78)$ & 1.76 & $\begin{array}{l}>105^{\circ} \mathrm{C} ; 135-100 \mathrm{Ma} \\
45-70^{\circ} \mathrm{C} ; 60-0 \mathrm{Ma}\end{array}$ \\
\hline $1.314(2079)$ & $1.000(297)$ & $2.023(601)$ & $10(20)$ & $126.3 \pm 9.7$ & $12.7 \pm 0.2(104)$ & 1.80 & $\begin{array}{l}85-100^{\circ} \mathrm{C} ; 120-75 \mathrm{Ma} \\
50-65^{\circ} \mathrm{C} ; 35-0 \mathrm{Ma}\end{array}$ \\
\hline $1.316(2079)$ & $0.421(81)$ & $1.018(196)$ & $36(11)$ & $106.0 \pm 14.3$ & $13.9 \pm 0.6(6)$ & 1.50 & $\begin{array}{l}>110^{\circ} \mathrm{C}, 180-80 \mathrm{Ma} \\
100-110^{\circ} \mathrm{C} ; 120-20 \mathrm{Ma}\end{array}$ \\
\hline $1.319(2079)$ & $1.183(528)$ & $2.181(973)$ & $91(20)$ & $139.1 \pm 8.5$ & $13.6 \pm 0.2(111)$ & 1.72 & $\begin{array}{l}>105^{\circ} \mathrm{C} ; 180-130 \mathrm{Ma} \\
65-85^{\circ} \mathrm{C} ; 120-60 \mathrm{Ma}\end{array}$ \\
\hline $1.321(2079)$ & $0.726(285)$ & $1.648(647)$ & $13(20)$ & $113.4 \pm 8.7$ & $13.4 \pm 0.1(105)$ & 1.48 & $\begin{array}{l}>105^{\circ} \mathrm{C} ; 150-105 \mathrm{Ma} \\
65-80^{\circ} \mathrm{C} ; 85-45 \mathrm{Ma}\end{array}$ \\
\hline $1.324(2079)$ & $1.430(162)$ & $2.569(291)$ & $56(10)$ & $143.2 \pm 14.6$ & $13.1 \pm 0.2(34)$ & 1.37 & $60-80^{\circ} \mathrm{C} ; 100-20 \mathrm{Ma}$ \\
\hline $1.327(2079)$ & $1.212(430)$ & $1.648(585)$ & $11(20)$ & $188.8 \pm 13.2$ & $13.2 \pm 0.2(102)$ & 1.87 & $60-80^{\circ} \mathrm{C} ; 105-25 \mathrm{Ma}$ \\
\hline - & - & - & - & - & - & - & No apatite \\
\hline $1.329(2079)$ & $1.912(698)$ & $2.869(1047)$ & $8(20)$ & $171.8 \pm 9.8$ & $12.6 \pm 0.2(108)$ & 1.76 & $60-80^{\circ} \mathrm{C} ; 85-20 \mathrm{Ma}$ \\
\hline $1.332(2079)$ & $0.966(504)$ & $1.311(684)$ & $46(20)$ & $190.0 \pm 12.4$ & $13.1 \pm 0.2(119)$ & 2.02 & $60-80^{\circ} \mathrm{C} ; 100-35 \mathrm{Ma}$ \\
\hline $1.335(2079)$ & $1.664(732)$ & 3.408 (1499) & $35(20)$ & $126.8 \pm 6.8$ & $13.8 \pm 0.1(112)$ & 1.33 & $\begin{array}{l}>115^{\circ} \mathrm{C} ; 150-125 \mathrm{Ma} \\
55-75^{\circ} \mathrm{C} ; 90-35 \mathrm{Ma}\end{array}$ \\
\hline $1.337(2079)$ & $1.123(509)$ & $1.510(684)$ & $<1(20)$ & $180.3 \pm 21.5^{*}$ & $13.3 \pm 0.2(107)$ & 1.76 & $55-75^{\circ} \mathrm{C} ; 85-15 \mathrm{Ma}$ \\
\hline $1.340(2079)$ & $1.663(540)$ & $2.057(668)$ & $60(20)$ & $209.3 \pm 13.5$ & $12.7 \pm 0.2(102)$ & 1.79 & $70-80^{\circ} \mathrm{C} ; 95-35 \mathrm{Ma}$ \\
\hline $1.503(2370)$ & $1.287(634)$ & $2.730(1345)$ & $26(20)$ & $137.7 \pm 7.7$ & $13.3 \pm 0.2(118)$ & 1.74 & $\begin{array}{l}100-110^{\circ} \mathrm{C}, 160-110 \mathrm{Ma} \\
55-75^{\circ} \mathrm{C}, 85-25 \mathrm{Ma}\end{array}$ \\
\hline $1.503(2370)$ & $0.899(358)$ & $2.104(838)$ & $3(20)$ & $121.8 \pm 11.4^{*}$ & $13.4 \pm 0.2(104)$ & 1.84 & $\begin{array}{l}>105^{\circ} \mathrm{C}, 165-120 \mathrm{Ma} \\
60-75^{\circ} \mathrm{C}, 75-20 \mathrm{Ma}\end{array}$ \\
\hline- & - & - & - & - & - & - & No apatite \\
\hline- & - & - & - & - & - & - & No apatite \\
\hline- & - & - & - & - & - & - & No apatite \\
\hline $1.504(2370)$ & $0.570(336)$ & $1.165(687)$ & $45(20)$ & $142.9 \pm 10.3$ & $13.2 \pm 0.2(106)$ & 2.19 & $55-80^{\circ} \mathrm{C}, 105-30 \mathrm{Ma}$ \\
\hline - & - & - & - & - & - & - & No apatite \\
\hline $1.335(2107)$ & $0.741(244)$ & $1.732(570)$ & $<1(20)$ & $113.6 \pm 14.5^{*}$ & $14.0 \pm 0.2(45)$ & 1.15 & $\begin{array}{l}>105^{\circ} \mathrm{C}, 145-95 \mathrm{Ma} \\
35-70^{\circ} \mathrm{C}, 90-0 \mathrm{Ma}\end{array}$ \\
\hline- & - & - & - & - & - & - & No apatite \\
\hline $1.335(2107)$ & $0.928(247)$ & $2.528(673)$ & $95(20)$ & $92.5 \pm 7.3$ & $14.1 \pm 0.3(15)$ & 1.32 & $>105^{\circ} \mathrm{C}, 125-80 \mathrm{Ma}$ \\
\hline $1.336(2107)$ & $0.646(63)$ & $1.845(180)$ & $<1(4)$ & $84.8 \pm 25.9^{*}$ & & & Insufficient data \\
\hline $1.336(2107)$ & $1.347(161)$ & $3.111(372)$ & $60(14)$ & $109.1 \pm 10.7$ & $13.5 \pm 0.3(6)$ & 0.67 & $\begin{array}{l}>125^{\circ} \mathrm{C}, 155-95 \mathrm{Ma} \\
30-70^{\circ} \mathrm{C}, 85-0 \mathrm{Ma}\end{array}$ \\
\hline $1.337(2107)$ & $0.518(176)$ & $1.616(549)$ & $12(20)$ & $81.2 \pm 9.2^{*}$ & $13.2 \pm 0.4(16)$ & 1.61 & $\begin{array}{l}>115^{\circ} \mathrm{C}, 220-75 \mathrm{Ma} \\
75-115^{\circ} \mathrm{C}, 100-45 \mathrm{Ma} \\
40-70^{\circ} \mathrm{C}, 40-0\end{array}$ \\
\hline- & - & - & - & - & - & - & No apatite \\
\hline $1.337(2107)$ & $0.926(183)$ & $2.308(456)$ & $22(20)$ & $101.2 \pm 9.3$ & $14.3 \pm 0.2(38)$ & 1.33 & $\begin{array}{l}>125^{\circ} \mathrm{C}, 135-90 \mathrm{Ma} \\
35-90^{\circ} \mathrm{C}, 105-0 \mathrm{Ma}\end{array}$ \\
\hline $1.337(2107)$ & $0.687(393)$ & $1.799(1029)$ & $6(20)$ & $96.4 \pm 6.3$ & $13.4 \pm 0.2(100)$ & 1.69 & $\begin{array}{l}>125^{\circ} \mathrm{C}, 130-95 \mathrm{Ma} \\
85-120^{\circ} \mathrm{C}, 120-70 \mathrm{Ma} \\
55-80^{\circ} \mathrm{C}, 65-20 \mathrm{Ma}\end{array}$ \\
\hline $1.338(2107)$ & $0.924(481)$ & $2.419(1259)$ & $49(20)$ & $96.5 \pm 5.8$ & $13.5 \pm 0.2(100)$ & 1.60 & $\begin{array}{l}>125^{\circ} \mathrm{C}, 125-90 \mathrm{Ma} \\
80-105^{\circ} \mathrm{C}, 110-60 \mathrm{Ma} \\
40-70^{\circ} \mathrm{C}, 55-0 \mathrm{Ma}\end{array}$ \\
\hline $1.338(2107)$ & $0.452(87)$ & $1.153(222)$ & $45(13)$ & $99.0 \pm 12.8$ & $14.0 \pm 0.6(4)$ & 1.30 & $>140^{\circ} \mathrm{C}, 140-75 \mathrm{Ma}$ \\
\hline $1.339(2107)$ & $0.926(218)$ & $2.435(573)$ & $<1(20)$ & $109.8 \pm 14.2^{*}$ & $13.1 \pm 0.2(100)$ & 1.51 & $\begin{array}{l}>120^{\circ} \mathrm{C}, 130-85 \mathrm{Ma} \\
80-120^{\circ} \mathrm{C}, 120-50 \mathrm{Ma} \\
45-75^{\circ} \mathrm{C}, 40-0 \mathrm{Ma}\end{array}$ \\
\hline
\end{tabular}


Table 1. Continued

\begin{tabular}{|c|c|c|c|c|c|}
\hline $\begin{array}{l}\text { Sample } \\
\text { number }\end{array}$ & Lat/long & Stratigraphic unit $\dagger$ & Stratigraphic division & $\begin{array}{l}\text { Stratigraphic } \\
\text { age } \dagger(\mathrm{Ma})\end{array}$ & $\begin{array}{l}\text { Elevation } \\
\text { (m asl) }\end{array}$ \\
\hline GC1070-37 & $-32.1760 / 22.548$ & Beaufort Group & Early-Middle Triassic & $250-230$ & 1526 \\
\hline GC1070-38 & $-32.1227 / 22.4477$ & Beaufort Group & Early-Middle Triassic & $250-230$ & 1642 \\
\hline GC1070-39 & $-32.3824 / 22.529$ & Beaufort Group & Early-Middle Triassic & $250-230$ & 842 \\
\hline GC1070-40 & $-33.0598 / 22.5347$ & Beaufort Group & Early-Middle Triassic & $250-230$ & 1002 \\
\hline GC1070-41 & $-33.2429 / 22.546$ & Dwyka Group & L. Carb.-Early Permian & $305-290$ & 888 \\
\hline GC1070-42 & $-33.3032 / 22.4775$ & Bokkeveld Group & Early-Middle Devonian & $405-385$ & 784 \\
\hline GC1070-43 & $-33.3868 / 22.56$ & Table Mtn Group & Ordovician-Silurian & $486-416$ & 674 \\
\hline GC1070-44 & $-33.4219 / 22.5498$ & Table Mtn Group & Ordovician-Silurian & $486-416$ & 597 \\
\hline GC1070-45 & $-33.4571 / 22.5600$ & Pre-Cape (Kansa Grp) & Cambrian-E. Ordovician? & $510-480$ & 486 \\
\hline GC1070-46 & $-33.6549 / 22.175$ & Kirkwood Fm? & Tithonian - Valanginian & $151-136$ & 283 \\
\hline GC1070-47 & $-33.6892 / 22.1503$ & Bokkeveld Group & Early-Middle Devonian & $405-385$ & 287 \\
\hline GC1070-48 & $-33.8639 / 22.0283$ & Table Mtn Group & Ordovician-Silurian & $486-416$ & 751 \\
\hline GC1070-49 & $-33.8894 / 22.0246$ & Table Mtn Group & Ordovician-Silurian & $486-416$ & 775 \\
\hline GC1070-50 & $-34.083 / 22.0521$ & Kirkwood Fm? & Tithonian - Valanginian & $151-136$ & 27 \\
\hline GC1059-58 & $-34.0267 / 24.8495$ & Table Mtn Group & Ordovician-Silurian & $486-416$ & 124 \\
\hline GC1059-59 & $-33.92293 / 25.02736$ & Kirkwood Fm? & Tithonian - Valanginian & $151-136$ & 39 \\
\hline GC1059-60 & $-33.5906 / 25.6542$ & Sundays R. Fm & Tithonian - Valanginian & $151-136$ & 40 \\
\hline GC1059-61 & $-33.5906 / 25.6542$ & Sundays R. Fm & Tithonian - Valanginian & $151-136$ & 40 \\
\hline GC1059-62 & $-33.4631 / 25.5416$ & Sundays R. Fm & Tithonian - Valanginian & $151-136$ & 71 \\
\hline GC1059-63 & $-33.4350 / 25.4389$ & Sundays R. Fm & Tithonian - Valanginian & $151-136$ & 125 \\
\hline GC1059-64 & $-33.4394 / 25.7459$ & Kirkwood Fm? & Tithonian - Valanginian & $151-136$ & 124 \\
\hline GC1059-65 & $-33.8411 / 25.6058$ & Kirkwood Fm & Tithonian - Valanginian & $151-136$ & 25 \\
\hline GC1059-66 & $-33.8069 / 25.4814$ & Sundays R. Fm & Tithonian - Valanginian & $151-136$ & 56 \\
\hline GC1059-67 & $-33.7542 / 25.4289$ & Kirkwood Fm? & Tithonian - Valanginian & $151-136$ & 142 \\
\hline GC1059-68 & $-33.5706 / 25.4292$ & Bokkeveld Gp & Early-Middle Devonian & $405-385$ & 364 \\
\hline GC1059-69 & $-33.4836 / 25.3356$ & Kirkwood Fm & Berriasian - Valanginian & $151-136$ & 183 \\
\hline GC1059-70 & $-33.6572 / 25.4553$ & Kirkwood Fm & Berriasian - Valanginian & $151-136$ & 144 \\
\hline GC1059-71 & $-33.3828 / 25.7096$ & Witpoort Fm, Wittenberg Gp & Famennian & $375-359$ & 310 \\
\hline GC1059-72 & $-33.7587 / 25.3929$ & Kirkwood Fm & Berriasian - Valanginian & $151-136$ & 109 \\
\hline GC1059-73 & $-33.7551 / 24.8074$ & Kirkwood Fm & Berriasian - Valanginian & $151-136$ & 54 \\
\hline
\end{tabular}

$\dagger$ All numerical values for stratigraphic ages assigned following Gradstein et al. (2012).

$\ddagger \rho_{\mathrm{s}}=$ spontaneous track density; $\rho_{\mathrm{i}}=$ induced track density; $\rho_{\mathrm{D}}=$ glass dosimeter track density. Numbers in parentheses show the number of tracks counted in determining all track densities.

§Probability that all single grain ages belong to a single population (Galbraith, 2005).

ๆCentral age (Galbraith, 2005)*, used for samples containing a significant spread in single grain ages $(P(\chi 2)<5 \%)$, otherwise the pooled age is quoted. All ages were calculated using the zeta calibration approach of Hurford \& Green (1983), using zeta values for CN5 glass of $380.4 \pm 5.7$ (samples GC903-17 to 24; GC998-16 to 19); $392.9 \pm 7.4$ (samples GC903-1 to 13 and 28 to 48; GC932-2 to 7; GC998-3 to 15). All errors quoted at $\pm 1 \sigma$. All analytical details are as described by Green (1986), with the exception that thermal neutron irradiations for this study showed a significant flux gradient, and the appropriate value of $\rho_{\mathrm{D}}$ for each sample was determined by linear interpolation through the stack of grain mounts. $\mathrm{Cl}$ contents were determined as described in the Supplementary data file, where further analytical details can be found.

\|Numbers in parentheses show the number of track lengths measured.

** Standard deviation of the track length distribution.

$\dagger$ †Thermal history solutions derived from AFTA data based on assumed heating and cooling rates of $1^{\circ} \mathrm{C} \mathrm{Ma}^{-1}$ and $10^{\circ} \mathrm{C} \mathrm{Ma}{ }^{-1}$, respectively. Quoted ranges correspond to $\pm 95 \%$ confidence limits on maximum/peak paleotemperature and onset of cooling in discrete episodes of heating and cooling. Conditions shown in italics are either only tentatively required by AFTA or provide an improved fit to the data but are not definitely required by the data. Text colour is coded to regional cooling events in Fig. 9. 


\begin{tabular}{|c|c|c|c|c|c|c|c|}
\hline $\begin{array}{l}\rho_{\mathrm{D}} \\
\left(10^{6} \text { tracks }\right. \\
\left.\mathrm{cm}^{-2}\right)\end{array}$ & $\begin{array}{l}\rho_{\mathrm{s}}+ \\
(106 \text { tracks } \\
\left.\mathrm{cm}^{-2}\right)\end{array}$ & $\begin{array}{l}\rho_{\mathrm{i}}^{\dagger}+ \\
\left(10^{6} \text { tracks }\right. \\
\left.\mathrm{cm}^{-2}\right)\end{array}$ & $\begin{array}{l}P\left(\chi^{2}\right) \S(\%) \\
\text { (no. of grains) }\end{array}$ & $\begin{array}{l}\text { Fission track } \\
\text { age }(\mathrm{Ma})\end{array}$ & $\begin{array}{l}\text { Mean track } \\
\text { length } \|(\mu \mathrm{m})\end{array}$ & $\begin{array}{l}\text { Std } \\
\operatorname{dev}^{* *} \\
(\mu \mathrm{m})\end{array}$ & $\begin{array}{l}\text { Thermal history } \\
\text { constraints } \dagger \dagger\end{array}$ \\
\hline $1.339(2107)$ & $1.024(339)$ & $2.565(849)$ & $62(20)$ & $100.9 \pm 7.0$ & $13.4 \pm 0.2(101)$ & 1.66 & $\begin{array}{l}>115^{\circ} \mathrm{C}, 130-95 \mathrm{Ma} \\
55-75^{\circ} \mathrm{C}, 60-10 \mathrm{Ma}\end{array}$ \\
\hline $1.339(2107)$ & $0.839(275)$ & $1.979(649)$ & $<1(20)$ & $116.3 \pm 15.6^{*}$ & $13.6 \pm 0.2(100)$ & 1.82 & $\begin{array}{l}>125^{\circ} \mathrm{C}, 135-90 \mathrm{Ma} \\
85-110^{\circ} \mathrm{C}, 115-75 \mathrm{Ma} \\
50-75^{\circ} \mathrm{C}, 65-15 \mathrm{Ma}\end{array}$ \\
\hline $1.340(2107)$ & $0.563(226)$ & $1.567(629)$ & $23(20)$ & $90.9 \pm 7.5$ & $14.1 \pm 0.2(101)$ & 1.91 & $\begin{array}{l}>130^{\circ} \mathrm{C}, 125-70 \mathrm{Ma} \\
100-130^{\circ} \mathrm{C}, 110-65 \mathrm{Ma} \\
60-85,50-5 \mathrm{Ma}\end{array}$ \\
\hline $1.340(2107)$ & $0.422(207)$ & $0.992(487)$ & $3(20)$ & $107.5 \pm 9.4$ & $14.5 \pm 0.2(79)$ & 1.36 & $\begin{array}{l}>125^{\circ} \mathrm{C}, 140-90 \mathrm{Ma} \\
45-80^{\circ} \mathrm{C}, 100-30 \mathrm{Ma}\end{array}$ \\
\hline $1.341(2107)$ & $1.028(280)$ & $2.800(763)$ & $32(20)$ & $92.9 \pm 6.9$ & $14.3 \pm 0.1(100)$ & 1.50 & $\begin{array}{l}>125^{\circ} \mathrm{C}, 120-85 \mathrm{Ma} \\
50-90^{\circ} \mathrm{C}, 95-35 \mathrm{Ma}\end{array}$ \\
\hline $1.341(2107)$ & $1.432(210)$ & $2.789(409)$ & $61(20)$ & $129.7 \pm 11.5$ & $13.3 \pm 0.2(100)$ & 1.55 & $\begin{array}{l}>110,180-115 \mathrm{Ma} \\
55-75^{\circ} \mathrm{C}, 70-15 \mathrm{Ma}\end{array}$ \\
\hline $1.342(2107)$ & $1.041(283)$ & $2.479(674)$ & $3(20)$ & $106.4 \pm 11.3^{*}$ & $13.4 \pm 0.2(56)$ & 1.37 & $\begin{array}{l}>125^{\circ} \mathrm{C}, 145-100 \mathrm{Ma} \\
75-100^{\circ} \mathrm{C}, 115-65 \mathrm{Ma}\end{array}$ \\
\hline $1.342(2107)$ & $1.195(561)$ & $3.055(1434)$ & $2(20)$ & $101.1 \pm 7.2^{*}$ & $13.9 \pm 0.2(77)$ & 1.32 & $\begin{array}{l}>100^{\circ} \mathrm{C}, 95-55 \mathrm{Ma} \\
40-70,55-0 \mathrm{Ma}\end{array}$ \\
\hline $1.342(2107)$ & $0.826(312)$ & $2.805(1059)$ & $16(20)$ & $74.8 \pm 5.2$ & $13.7 \pm 0.2(82)$ & 1.52 & $\begin{array}{l}>100^{\circ} \mathrm{C}, 95-55 \mathrm{Ma} \\
40-75,55-0 \mathrm{Ma}\end{array}$ \\
\hline $1.343(2107)$ & $0.958(223)$ & $2.568(598)$ & $<1(20)$ & $94.9 \pm 13.9^{*}$ & $13.0 \pm 0.5(18)$ & 1.94 & $\begin{array}{l}>100^{\circ} \mathrm{C}, 140-90 \mathrm{Ma} \\
70-90^{\circ} \mathrm{C}, 85-15 \mathrm{Ma}\end{array}$ \\
\hline $1.343(2107)$ & $2.393(381)$ & $3.712(591)$ & $41(20)$ & $162.6 \pm 11.5$ & $12.4 \pm 0.1(100)$ & 1.45 & $\begin{array}{l}>110,235-170 \mathrm{Ma} \\
75-95^{\circ} \mathrm{C}, 155-45 \mathrm{Ma} \\
40-65,30-0 \mathrm{Ma}\end{array}$ \\
\hline- & - & - & - & - & - & - & No apatite \\
\hline- & - & - & - & - & - & - & No apatite \\
\hline- & - & - & - & - & - & - & No apatite \\
\hline $1.639(2543)$ & $0.660(349)$ & $1.133(599)$ & $23(20)$ & $184.9 \pm 13.4$ & $13.5 \pm 0.2(113)$ & 1.66 & $\begin{array}{l}>105^{\circ} \mathrm{C}, 235-175 \mathrm{Ma} \\
65-80^{\circ} \mathrm{C} ; 140-65 \mathrm{Ma}\end{array}$ \\
\hline- & - & - & - & - & - & - & No apatite \\
\hline $1.635(2543)$ & $0.731(370)$ & $1.451(734)$ & $18(20)$ & $159.9 \pm 11.1$ & $13.3 \pm 0.2(110)$ & 2.51 & $65-85^{\circ} \mathrm{C} ; 105-45 \mathrm{Ma}$ \\
\hline $1.632(2543)$ & $1.229(550)$ & $2.056(920)$ & $<1(20)$ & $189.7 \pm 16.9^{*}$ & $13.6 \pm 0.2(107)$ & 1.78 & $50-85^{\circ} \mathrm{C} ; 130-40 \mathrm{Ma}$ \\
\hline $1.628(2543)$ & $0.725(452)$ & $1.324(826)$ & $18(20)$ & $172.7 \pm 11.2$ & $13.4 \pm 0.2(113)$ & 1.72 & $50-75^{\circ} \mathrm{C} ; 100-20 \mathrm{Ma}$ \\
\hline $1.625(2543)$ & $1.073(705)$ & 2.059 (1353) & $<1(20)$ & $192.0 \pm 19.4^{*}$ & $14.0 \pm 0.1(112)$ & 1.55 & $60-80^{\circ} \mathrm{C} ; 115-50 \mathrm{Ma}$ \\
\hline $1.622(2543)$ & $1.174(684)$ & $1.920(1119)$ & $<1(20)$ & $198.9 \pm 16.6^{*}$ & $13.4 \pm 0.2(123)$ & 1.98 & $65-85^{\circ} \mathrm{C} ; 125-60 \mathrm{Ma}$ \\
\hline $1.618(2543)$ & $1.096(378)$ & $1.557(537)$ & $4(20)$ & $223.0 \pm 20.8^{*}$ & $13.8 \pm 0.2(116)$ & 1.75 & $<110^{\circ} \mathrm{C}$; post-dep'n \\
\hline $1.615(2543)$ & $0.781(257)$ & $1.419(467)$ & $21(20)$ & $172.2 \pm 14.2$ & $13.8 \pm 0.2(112)$ & 2.07 & $40-80^{\circ} \mathrm{C} ; 120-30 \mathrm{Ma}$ \\
\hline $1.611(2543)$ & $0.903(558)$ & $1.401(866)$ & $9(20)$ & $200.8 \pm 12.2$ & $13.3 \pm 0.2(112)$ & 2.17 & $65-85^{\circ} \mathrm{C} ; 130-55 \mathrm{Ma}$ \\
\hline $1.608(2543)$ & $1.565(525)$ & $2.570(862)$ & $47(20)$ & $189.6 \pm 11.7$ & $12.8 \pm 0.2(111)$ & 2.17 & $\begin{array}{l}95-105^{\circ} \mathrm{C}, 205-120 \mathrm{Ma} \\
65-85^{\circ} \mathrm{C} ; 115-60 \mathrm{Ma}\end{array}$ \\
\hline $1.604(2543)$ & $1.163(470)$ & $2.022(817)$ & $65(21)$ & $178.8 \pm 11.4$ & $13.3 \pm 0.2(110)$ & 2.07 & $65-85^{\circ} \mathrm{C} ; 115-60 \mathrm{Ma}$ \\
\hline $1.601(2543)$ & $0.748(544)$ & $1.307(950)$ & $<1(20)$ & $177.7 \pm 16.9^{*}$ & $13.1 \pm 0.2(106)$ & 1.79 & $60-80^{\circ} \mathrm{C} ; 95-30 \mathrm{Ma}$ \\
\hline $1.598(2543)$ & $1.547(369)$ & $2.620(625)$ & $7(20)$ & $182.7 \pm 13.0$ & $13.1 \pm 0.2(63)$ & 1.91 & $\begin{array}{l}>115^{\circ} \mathrm{C} ; 250-180 \mathrm{Ma} \\
60-90^{\circ} \mathrm{C} ; 140-35 \mathrm{Ma}\end{array}$ \\
\hline - & - & - & - & - & - & - & No apatite \\
\hline- & - & - & - & - & - & - & No apatite \\
\hline
\end{tabular}


Table 2. Vitrinite reflectance results and sample details; Algoa and Gamtoos Basin

\begin{tabular}{lllllll}
\hline Sample number & Lat/long & Stratigraphic unit & $\begin{array}{l}\text { Stratigraphic } \\
\text { age* }(\mathrm{Ma})\end{array}$ & $\begin{array}{l}\text { Mean } \\
R_{\mathrm{o}} \text { max } \dagger \\
(\%)\end{array}$ & $\begin{array}{l}\text { Number of } \\
\text { measurements }\end{array}$ & $\begin{array}{l}\text { Maximum } \\
\text { paleotemperature }+\left({ }^{\circ} \mathrm{C}\right)\end{array}$ \\
\hline GC1059-59.1 & $-33.9229 / 25.0274$ & Kirkwood sst & $151-136$ & 0.52 & 2 & 86 \\
GC1059-60.1 & $-33.5906 / 25.6542$ & Sundays R. Fm & $151-136$ & 0.44 & 3 & 74 \\
GC1059-62.1 & $-33.4631 / 25.5416$ & Sundays R. Fm & $151-136$ & 0.44 & 2 & 74 \\
GC1059-62.1 & $-33.4631 / 25.5416$ & Sundays R. Fm & $151-136$ & $0.40 \S$ & $25 \S$ & 66 \\
GC1059-63.1 & $-33.4350 / 25.4389$ & Kirkwood Fm? & $151-136$ & 0.54 & 1 & 90 \\
GC1059-64.1 & $-33.4394 / 25.7459$ & Kirkwood Fm & $151-136$ & 0.32 & 2 & 50 \\
GC1059-65.1 & $-33.8411 / 25.6058$ & Sundays R. Fm & $151-136$ & 0.39 & 25 & 65 \\
GC1059-66.1 & $-33.8069 / 25.4814$ & Sundays R. Fm & $151-136$ & $0.36 \S$ & $3 \S$ & 59 \\
GC1059-67.1 & $-33.7542 / 25.4289$ & Kirkwood Fm & $151-136$ & 0.45 & 3 & 76 \\
GC1059-70.1 & $-33.6572 / 25.4553$ & Kirkwood Fm & $151-136$ & 0.51 & 2 & 84 \\
GC1059-70.2 & $-33.6572 / 25.4553$ & Kirkwood Fm & $151-136$ & 0.54 & 5 & 90 \\
GC1059-73.1 & $-33.7551 / 24.8074$ & Enon - & $151-136$ & 0.33 & 1 & 50 \\
& & Kirkwood & & & & \\
\hline
\end{tabular}

*All numerical values for stratigraphic ages assigned following Gradstein et al. (2012).

$\dagger$ Mean maximum vitrinite reflectance: determinations by Keiraville Konsultants (Prop. Alan Cook (dec.); Chief Analyst Paddy Ranasinghe) based on identification of indigenous vitrinite using petrographic techniques in polished thick rock sections, determining maximum reflectance using a rotating stage, following procedures outlined by Cook (1982).

$\$$ Maximum paleotemperatures calculated using the algorithm of Burnham \& Sweeney (1989) using an assumed heating rate of $1^{\circ} \mathrm{C}$ Myr-1.

$\S$ In these samples, no vitrinite was observed so reflectance was measured in the inertinite maceral. Equivalent VR was derived from the mean inertinite reflectance using a conversion based on measurements in a wide range of environments. Number of measurements in these samples denote the number of fields measured in defining the mean inertinite reflectance.

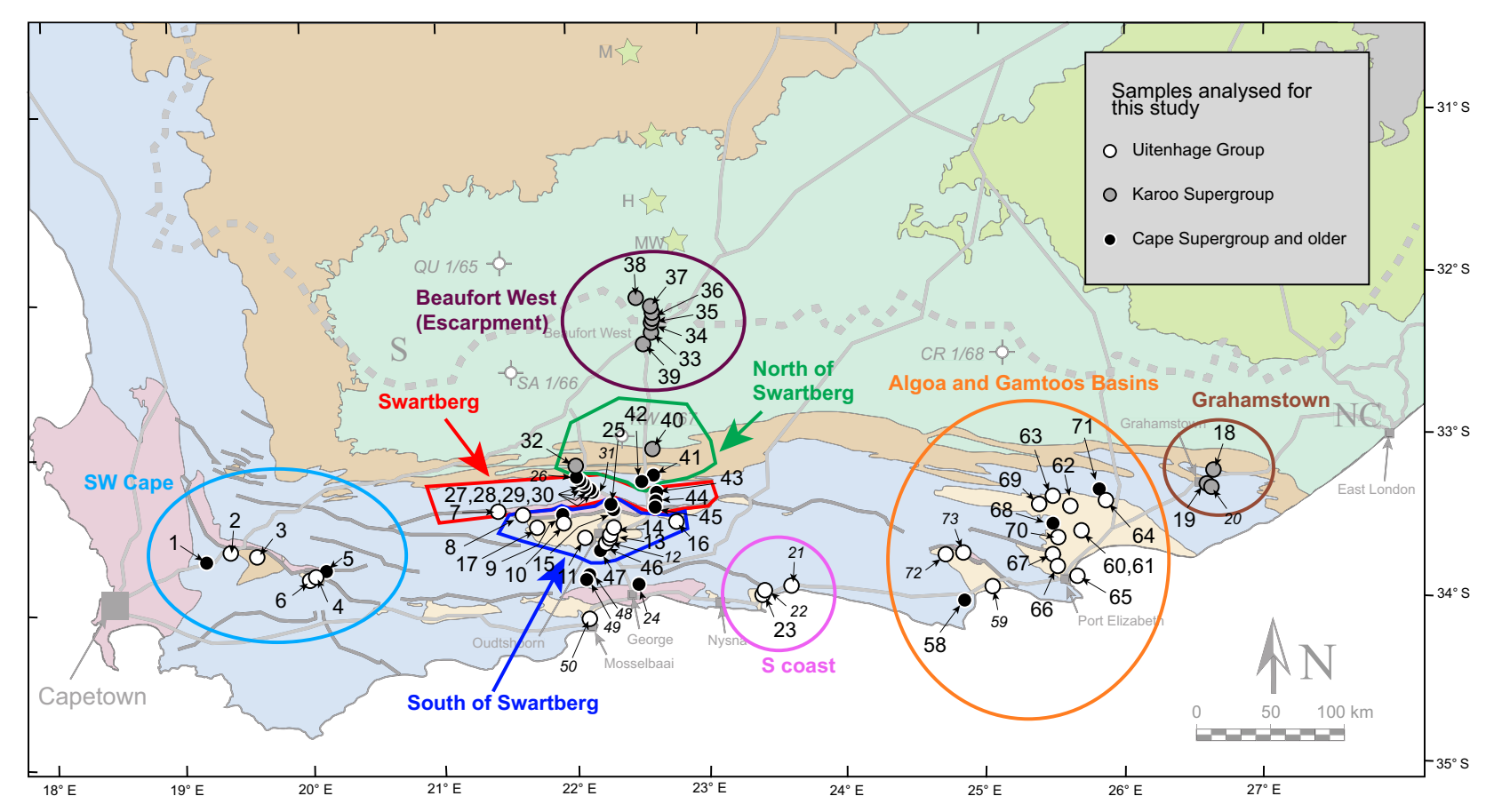

Fig. 5. Locations of samples analysed using AFTA and VR for this study. Latitudes and longitudes are provided in Tables 1 and 2. Samples denoted in smaller size italic type failed to yield apatite. Geographical regions indicate the division of data for discussion and used in Fig. 7.

(2003) (see Green \& Duddy, 2012 for details), and similar results to those presented here would be obtained using kinetic models based on those data if implemented in similar fashion. Further background information is provided in Appendix C of the supplementary data file.
Thermal history solutions derived from AFTA data in samples from this study using this approach are summarised in Table 1, with the stated intervals representing $95 \%$ confidence limits on the maximum paleotemperature and timing of cooling in one or more episodes. Maximum paleotemperatures indicated by the VR data are 
Fig. 6. Mean track length plotted against apatite fission track ages for samples from this study plus published data in outcrop samples from southwest Africa. Error bars represent analytical uncertainties from Table 1 and are plotted at the $2 \sigma$ level (i.e. $95 \%$ confidence limits). Results in samples of 'basement' (Paleozoic and older) from western and central locations in this study, plus data from and Mesozoic sandstones in western locations are similar to published data while data from eastern locations around the Algoa and Gamtoos Basins plot in a separate region, pointing to a different history in this region.

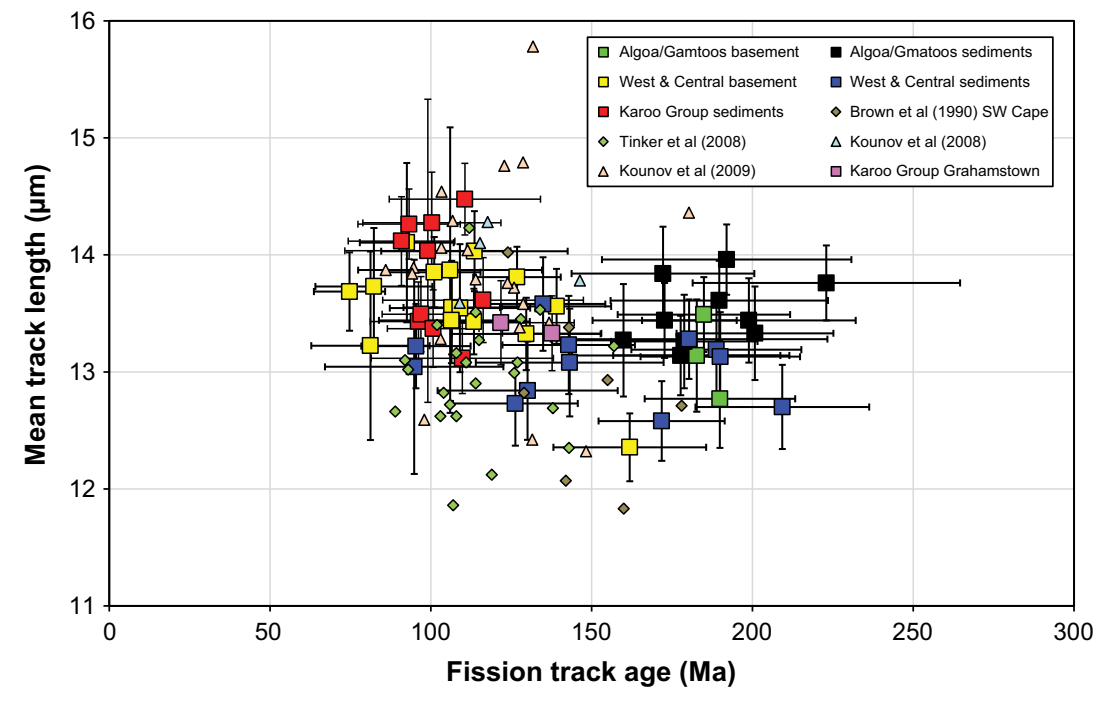

listed in Table 2. These are generally consistent with those from AFTA in adjacent samples.

\section{Definition and characterisation of regional paleo-thermal episodes}

Timing constraints on the onset of cooling (95\% confidence intervals) derived from all samples in this study are compared in Fig. 7, with samples grouped into the geographical regions illustrated in Fig. 5. The size of these confidence regions in individual samples is affected by a combination of factors, including not only data quality but also the paleotemperature from which a sampled cooled. The timing of cooling below $c a .110^{\circ} \mathrm{C}$ can usually be determined with greatest precision, whereas uncertainty in the timing of cooling from paleotemperatures around $60-70^{\circ} \mathrm{C}$ usually depends strongly on the quality of the track length data.

Apatite fission track analysis data in many of the basement samples require at least two discrete cooling episodes. In these samples, the earlier episode typically represents the time at which the sample cooled to a sufficiently low temperature for tracks to be retained, and is usually constrained principally by the fission track age data while the later event is recorded by shortening of the dominant mode of the track length distribution. In some samples (including many of the Karoo Supergroup samples from locations north of Beaufort West, plus some basement samples, e.g. GC1070-43 and -47), three paleo-thermal episodes are required to explain all aspects of the data. In these samples, the earliest event is again defined largely by the fission track age data while the intermediate event is defined from a distinct shorter component of tracks and the most recent event is again defined from the shortening of the main mode of the track length distribution. But, we emphasise that the temperature and time constraints in each episode are defined from both aspects of the data.

In general, results in samples within each of the geographic regions defined in Fig. 5 show a high degree of consistency. For example, data in all samples from the Algoa and Gamtoos Basins, in the southeast of the study area, show evidence of a single episode of heating and cooling after deposition of the Uitenhage Group, while all three basement samples from the basin margins show two events, one prior to deposition of the sedimentary units and one after. In five of seven samples of Karroo Sandstones analysed around Beaufort West the data define three cooling episodes with mutually consistent timing constraints. Data from sample GC1070-37 only resolve the earliest and latest events, while in sample GC1070-35, from a dolerite sill, only a single event is defined due to a combination of low apatite yield, low uranium content and a small number of track lengths.

If samples from adjacent locations cooled from similar paleotemperatures with consistent timing constraints, it seems reasonable to assume that the data represent a common cooling episode. On this basis, by combining constraints on the onset of cooling in different samples in each area, and then extending the resulting synthesis across the entire area, we can define the timing of key regional paleo-thermal episodes (i.e. periods at which samples began to cool from elevated paleotemperatures). As shown in Fig. 7, results in all samples analysed in this study can be explained in terms of five regionally synchronous cooling events which began in the following intervals (with stratigraphic intervals assigned based on the timescale of Gradstein et al., 2012):

205-180 Ma (latest Triassic - Early Jurassic; Rhaetian-Toarcian)

145-130 Ma (Early Cretaceous; Berriasian-Hauterivian)

120-100 Ma (Early to mid-Cretaceous; AptianAlbian)

85-75 Ma (Late Cretaceous; Santonian-Campanian)

30-20 Ma (Cenozoic; Oligocene-early Miocene)

Almost all timing constraints from AFTA in all samples are consistent with one of these intervals. Only a few exceptions are evident, one being the later cooling 
episode identified in sample GC1070-19 (from near Grahamstown), with an upper limit of $75 \mathrm{Ma}$ which just fails to overlap with the $85-75 \mathrm{Ma}$ interval derived from the other samples in Fig. 7. Another exception is sample GC1070-42 (North of Swartberg). Two cooling events are identified from the AFTA data, as also in adjacent samples GC1070-40 and -41, with similar maximum paleotemperatures in each case, but the timing constraints on the two events in sample GC1070-42 are not consistent with those in the adjacent samples. While it is possible that these 'mis-fit' samples began to cool at slightly different times to adjacent samples, it seems more likely, given that over 90 timing estimates in Fig. 7 are consistent with one of the five episodes listed above, that the errant values in samples GC1070-19 and -42 (also one event in sample GC1070-5) are statistical outliers. On this basis, we regard the events defined in Fig. 7 as representing the most reliable estimates of the timing of key cooling events across the region.

Maps of the paleotemperature from which samples cooled in each episode, as identified in Fig. 7, are shown in Fig. 8. Schematic illustrations of the thermal history of representative samples across the region, based on the discussion of results so far, are presented in Fig. 9. These also integrate evidence from geological constraints, for example, where 'basement' rocks (as defined here) are overlain by Mesozoic sedimentary units. These histories illustrate the complex variation in thermal history across the region, and display a different style of variation to those adopted in previous thermochronological studies of southern Africa, the implications of which are discussed further below.

\section{EPISODIC DEVELOPMENT OF THE SOUTHERN MARGIN OF AFRICA}

The results discussed above suggest that the region that now comprises southern Africa has undergone at least five major post-Paleozoic paleo-thermal episodes of cooling. The nature of these episodes, and their likely impact on the present-day landscape, is discussed below.

\section{Latest Triassic - early Jurassic episode}

Cooling from paleotemperatures generally $>100^{\circ} \mathrm{C}$ which began in the interval $205-180 \mathrm{Ma}$ is identified in three samples from the basement margins to the Algoa and Gamtoos Basins, and also in one sample from the southern margin of the Oudtshoorn Basin (Fig. 8b). Cooling at this time has also been identified in several other regions of southern Africa (e.g. Green et al., 2009) where the effects of later (particularly Cretaceous) paleo-thermal episodes have been sufficiently low to allow preservation of earlier events. Thus, it seems likely that this cooling episode originally affected a much wider area but its effects have been overprinted by later episodes in many regions.

The onset of cooling in this episode correlates well with a change in the regional geodynamic regime highlighted by Tankard et al. (2009), the onset of rifting between Africa and Madagascar (Macdonald et al., 2003) and the extensive igneous activity which terminated the Karoo sequence, as discussed earlier (Fig. 3). Cooling at this time may be related to tectonically driven regional exhumation, or alternatively could be explained in terms of hydrothermal circulation associated with Early Jurassic igneous activity, or perhaps a combination of both. Given the general absence of any evidence of Karoo igneous activity around the Algoa and Gamtoos Basins, cooling primarily due to exhumation seems more likely in this area. Such an interpretation is consistent with the significant erosional unconformity at the base of the Uitenhage Group in this area and it seems likely that this event represents a period of denudation prior to the onset of deposition of the Uitenhage Group across the southern margin of Africa. This event may have affected much of the study area, as above, but given the severity of later events over most of the region, it is unlikely that present-day landscapes preserve any significant imprint of this event.

\section{Early Cretaceous episode}

Cooling from $>105^{\circ} \mathrm{C}$ or above which began in the interval $145-130 \mathrm{Ma}$ is identified in four basement samples from the footwall to the Oudtshoorn Basin within the Cango Inlier (GC1070-8, -9 and -15) and two samples of the Dwyka tillite (GC1070-18, -19) from close to Grahamstown (Fig. 8c). One sample from north of the Swartberg Range (GC1070-42) also appears to show cooling at this time, although comparison with adjacent samples suggests that this result is a statistical outlier and is more likely to represent the Early to mid-Cretaceous event (below), and we favour this interpretation.

The overlap in timing between the onset of this cooling episode and the depositional age of the Uitenhage Group suggests that Early Cretaceous cooling in the northern basement margin to the Oudtshoorn Basin could be

Fig. 7. Timing constraints on cooling events identified from AFTA in samples analysed for this study (from Table 1), separated into regions as in Fig. 5, illustrating definition of the five major regional cooling episodes identified in this study. (It is emphasised that these are extracted from the AFTA data using techniques explained in the text and in more detail in the Supplementary Data file, and do not relate directly to the measured fission track ages.) Three constraints assigned to the Late Cretaceous (85-75 Ma) episode and one attributed to Early to mid-Cretaceous (120-100 Ma) cooling which are not consistent with the synthesis are regarded as statistical outliers. Depositional age ranges are indicated by the grey boxes. Basement samples cooled below $c a .110^{\circ} \mathrm{C}$ (the precise temperature depending on $\mathrm{wt} \% \mathrm{Cl}$ in each sample) at different times in different regions, while almost all samples show evidence of cooling which began in the interval 85-75 Ma (Santonian-Campanian). Western and Central samples also show evidence for Cenozoic cooling which is not seen in samples further east. 


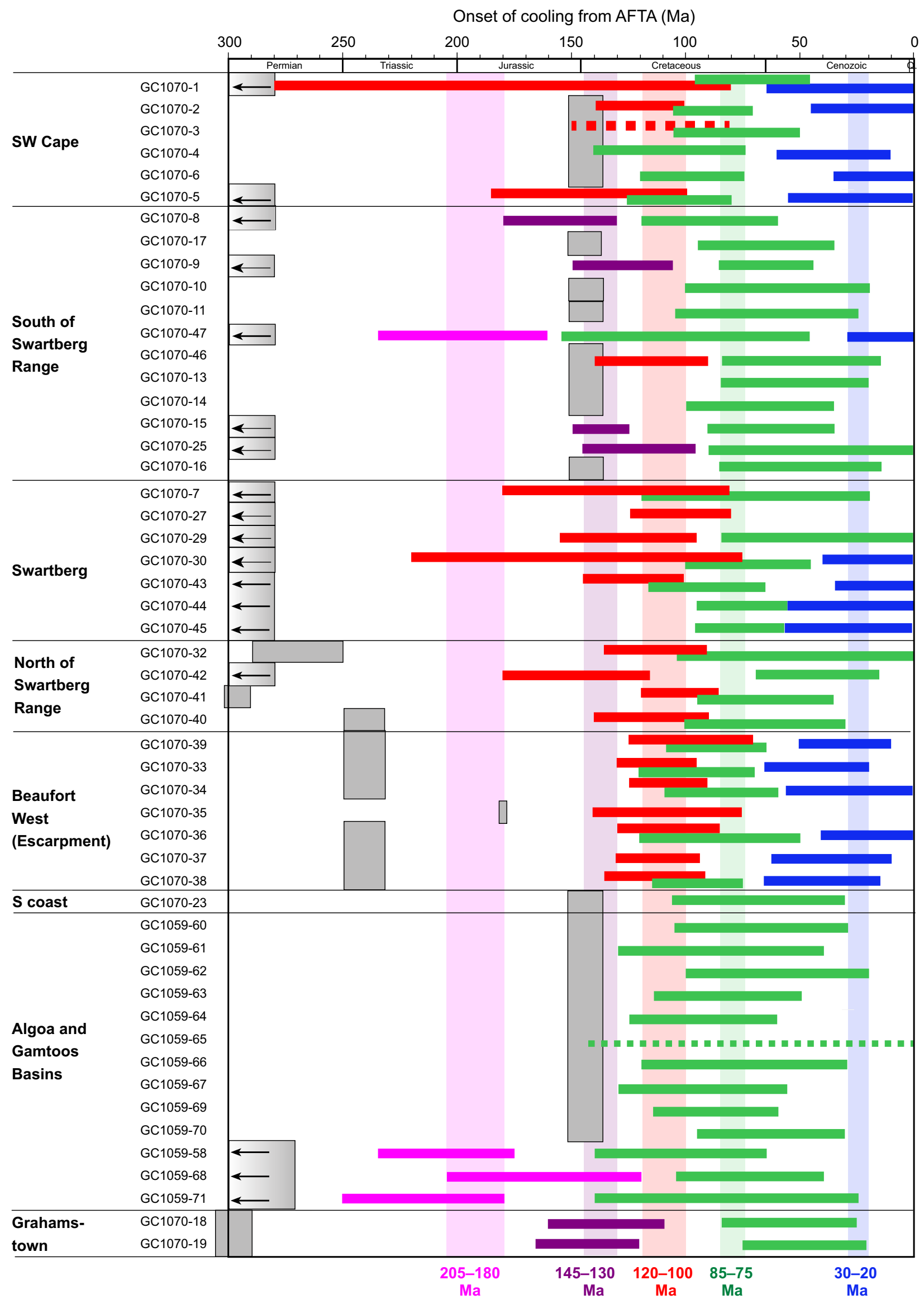


explained in terms of footwall uplift during development of the Late Jurassic-early Cretaceous rift basin. However, this interpretation would not apply to the two samples near Grahamstown (Fig. 8c). Restriction of Early Cretaceous denudation mainly to the Cango Inlier (Figs 2, 8c and $10 \mathrm{c}$ ) raises the possibility that the whole block was uplifted and denuded differentially with regard to the surrounding regions at this time, and an interpretation in terms of differential block uplift might also explain the cooling at this time identified near Grahamstown.

To the south of the Cango Inlier, the Oudtshoorn Basin was subsiding at this time, with deposition of Uitenhage Group sediments. All samples to the north of the Cango inlier only cooled to temperatures at which tracks could be retained in the subsequent Early to mid-Cretaceous event (Figs $8 \mathrm{~d}$ and 10d) and so it is not clear if this northern region also underwent significant cooling in the earlier (145-130 Ma) episode.

\section{Early to mid-Cretaceous episode}

Cooling which began in the interval $120-100 \mathrm{Ma}$ is most strongly expressed in samples of Karoo Supergroup sandstones around Beaufort West, and basement samples from the Swartberg Range (Fig. 8d), most of which cooled from paleotemperatures $>100^{\circ} \mathrm{C}$ in this episode. In contrast, samples from locations to the south of the Swartberg Range show no evidence of cooling at this time, with the single exception of sample GC1070-46, of Uitenhage Group sandstone from the southern margin of the Oudtshoorn Basin, which cooled from $>100^{\circ} \mathrm{C}$ in this episode. Since Early to mid-Cretaceous cooling is not identified in any other sample south of the Cango fault, which forms the northern margin of the Oudtshoorn Basin (Fig. 2), this result remains something of an anomaly at present. Given the uncertainty regarding precise depositional ages within the Uitenhage Group, it is possible that
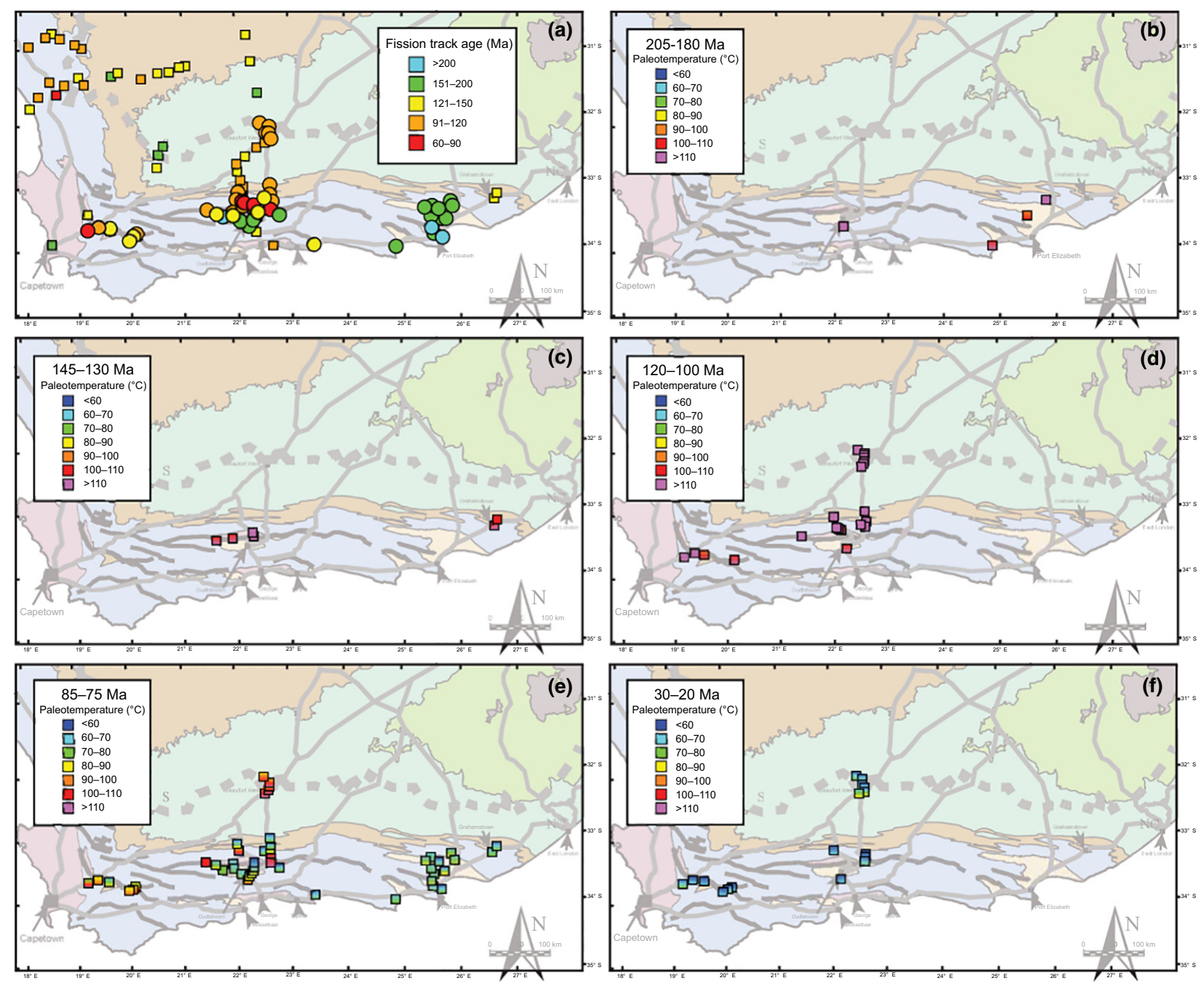

Fig. 8. Maps of apatite fission track ages (a: circles - this study; squares - published data; for references see text) and paleotemperatures (b-e) in individual samples in the five major regional paleo-thermal episodes identified in Fig. 7 (values for individual samples are listed in Table 1). 
this event in sample GC1070-46 represents pre-depositional cooling in a sedimentary unit with a younger depositional age than elsewhere.

Early to mid-Cretaceous cooling is also identified in samples from the Southwest Cape region, where basement samples GC1070-1 and -5 cooled from $>125^{\circ} \mathrm{C}$ and $>105^{\circ} \mathrm{C}$, respectively, in this episode. Uitenhage Group sample GC1070-2 also cooled from $>125^{\circ} \mathrm{C}$ at this time, while sample GC1070-3 (also Uitenhage Group) shows tentative evidence for cooling from a maximum postdepositional temperature between $95^{\circ} \mathrm{C}$ and $130^{\circ} \mathrm{C}$ in this episode (Table 1).

The regional extent of this episode, with many samples cooling from paleotemperatures greater than $125^{\circ} \mathrm{C}$ at this time, suggests that when cooling began, present-day outcrops were covered by significant amounts of additional section, although exact amounts are not clear. Identification of this episode in samples of Uitenhage Group sediments implies that at least for these samples this additional section represents burial by an additional thickness of cover deposited after the preserved sedimentary section.

This episode is strongly expressed north of the Cango Inlier (Figs $8 \mathrm{~d}$ and 10d), but samples within the Inlier and to the south show no evidence of cooling in this event. This shows that the major contribution to cooling at this time must have been denudation, involving major upward movements on the northern boundary fault to the Cango Inlier. No similar structural control is evident for this episode in samples from the southwest Cape region (Fig. 8d). Identification of Early-mid Cretaceous cooling in the SW Cape region suggests that this event may also have affected 'basement' regions to the south of the Oudtshoorn Basin, towards the coast. None of the samples analysed from this region for this study yielded any apatite, but published data, discussed below, strongly support the suggestion of major Early-mid Cretaceous cooling in this region.

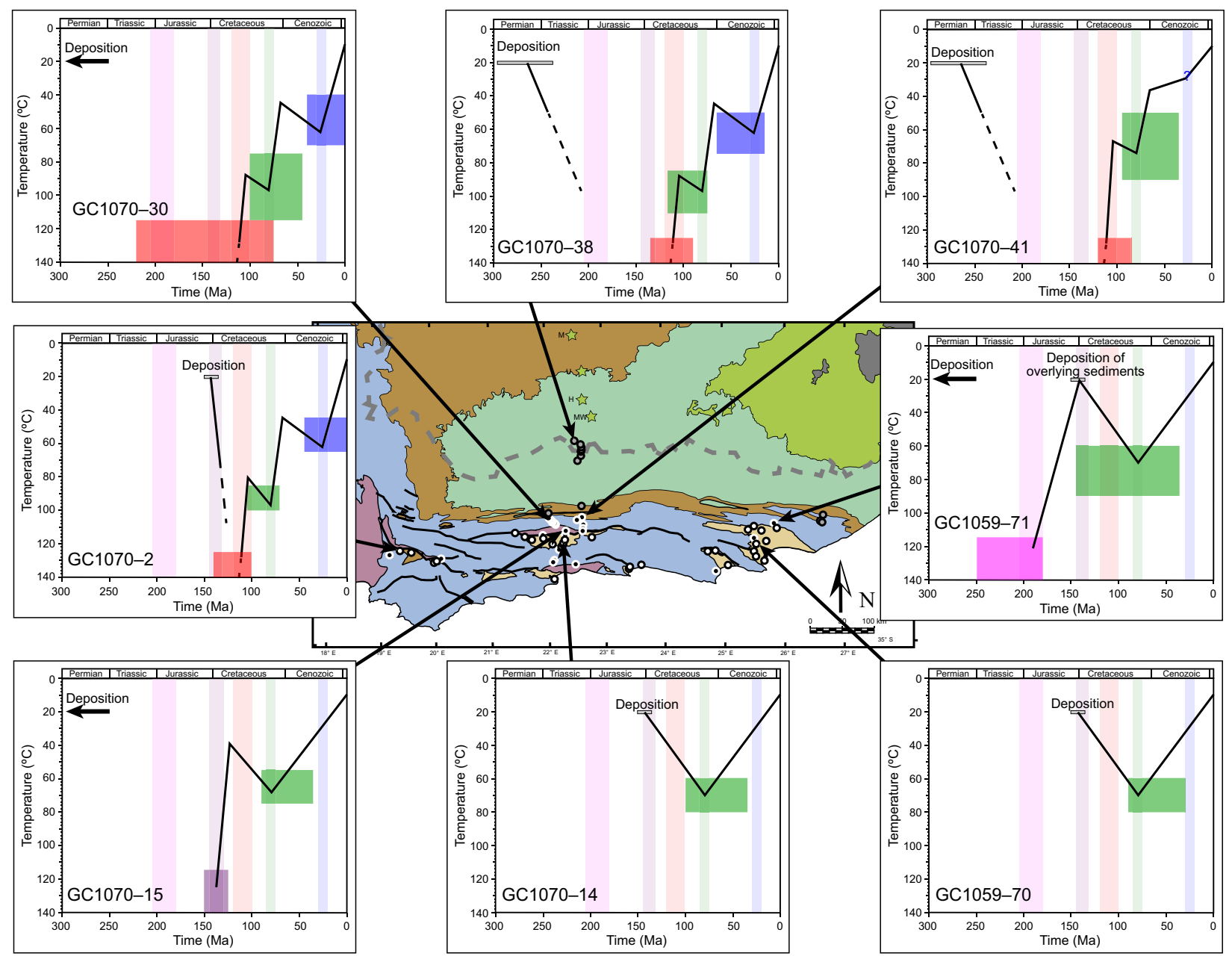

Fig. 9. Schematic representations of thermal histories derived from AFTA and VR data in selected samples across the region. Temperature-time boxes represent $95 \%$ confidence limits on the magnitude of maximum/peak paleotemperatures and the onset of cooling, as listed in Table 1. Although in detail the shape of the uncertainty regions around the paleo-thermal maxima are complex, these are reduced to simple rectangles here for clarity. We emphasise that AFTA data cannot constrain the entire thermal history of a sample, so we focus on defining the main paleo-thermal episodes that exert a dominant control on the data in individual samples. In some cases, the presence of sedimentary rocks overlying basement provides further constraints, as shown. Apart from these constraints, the form of the thermal history in each sample is not constrained, and the black lines are for illustrative purposes only. 


\section{Late Cretaceous episode}

In contrast to the other paleo-thermal episodes revealed by AFTA, which all demonstrate at least some degree of structural control, cooling which began in the interval 85-75 Ma (Santonian-Campanian) is observed over the entire study area (Fig. 8e). Late Cretaceous paleotemperatures in individual samples show a clear pattern of regional variation in Fig. 8e, increasing from $c a .60^{\circ} \mathrm{C}$ to $80^{\circ} \mathrm{C}$ in the east in and around the Algoa and Gamtoos Basins, to slightly higher values of $c a .70-90^{\circ} \mathrm{C}$ in and around the Oudtshoorn Basin and locally higher within the core of the Swartberg Range (Fig. 10e), increasing to values around $100^{\circ} \mathrm{C}$ or more to the north in the Karoo Basin around Beaufort West and the Great Escarpment and also in the westernmost samples of the southwest Cape region.

Late Cretaceous paleotemperatures derived from AFTA in the sedimentary rocks of the Algoa and Gamtoos Basins are generally consistent with those derived from VR in adjacent samples, confirming that these sedimentary units cooled from their maximum post-depositional paleotemperatures in this episode. A significant feature of this episode in the southeast is the consistency between Late Cretaceous paleotemperatures in samples of sedimentary rocks of the Algoa and Gamtoos Basins and those in basement samples from adjacent basin margins. In contrast, significant local variation is evident between samples at similar elevations in the Oudtshoorn Basin and basement to the north in the Swartberg Range, as discussed further below.

Santonian-Campanian cooling post-dates deposition of the Late Jurassic to Early Cretaceous Uitenhage Group, and is recognised in samples of this unit throughout the Algoa and Gamtoos Basins and basement flanks in the east, the Oudtshoorn Basin and surrounding regions in the centre of the region, and in Uitenhage Group outliers westwards towards Cape Town (Figs 8d and 10d). These paleotemperatures must therefore represent the effects of additional Cretaceous burial of these regions, prior to exhumation that began between 85 and $75 \mathrm{Ma}$, and the present Uitenhage Group units therefore represent the remnants of a formerly much thicker section.

As the magnitude of Santonian-Campanian paleotemperatures generally show a smooth pattern of variation (except for samples within the Swartberg Range, as above), with similar values in both basins and adjacent basement margins, and also because in most cases at least the southern basin margins are depositional, it seems likely that the basement margins must also have been buried by the same cover sequence that was deposited in the basins. On fault-controlled northern basin margins, the requirement for reburial is less clear (as cooling could, in principle, reflect removal of basement), but the similarity of the Santonian-Campanian paleotemperatures across these structures suggests that by the time that exhumation began differential movements across faults has ceased and the hanging wall and footwall moved together. If this is so, then it is likely that both hanging walls and footwalls, together with the preserved basin sediments, were buried by post-Late Jurassic-Early Cretaceous deposits prior to Santonian-Campanian exhumation.

\section{Cenozoic episode}

Evidence for Cenozoic cooling, which began between 30 and $20 \mathrm{Ma}$, is clearly focussed in the west of the study area (Fig. 8f), and is more pronounced in the mountainous areas of the southwest Cape and the Swartberg region, and also around the Great Escarpment near Beaufort West. The lack of evidence for any detectable Cenozoic cooling in the southeast in and around the Algoa and Gamtoos Basins, where relief is much more subdued, is particularly notable. The focussing of Cenozoic cooling in more mountainous regions today provides a strong indication that this cooling represents denudation related to development of the modern-day relief.

\section{INSIGHTS FROM RELATIONSHIPS BETWEEN PALEOTEMPERATURES AND PRESENT-DAY RELIEF}

The variation in paleotemperatures through vertical rock sections, and their relationship with present-day landforms, can reveal the nature of the processes responsible for the paleo-thermal effects identified from AFTA (see Green et al., 2013, for a review). Analysis of samples from vertical rock sections over a limited horizontal distance has been possible in a limited number of locations in this study, and as discussed below, these results provide key insights into mechanisms of heating and cooling and the development of the present-day landscape. In other locations, correlation between cooling events and landscape elements allows additional constraints on the processes revealed by the AFTA and VR data collected in this study.

\section{Oudtshoorn Basin and Swartberg range}

Thermal history interpretations derived from AFTA data in samples around the Oudtshoorn Basin and the Swartberg Range, to the north (Fig. 10), provide evidence for a series of major paleo-thermal discontinuities, indicating tectonic offsets across major structures in this region.

Four samples collected from the Cango Inlier in the footwall to the Oudtshoorn Basin (GC1070-7, -9, -15 and -25 , Table 1) all cooled from $>105^{\circ} \mathrm{C}$ or above in the Early Cretaceous episode (Fig. 10c). Sample GC1070-45, collected from a similar setting at the eastern end of the Cango inlier, cooled from $>100^{\circ} \mathrm{C}$ in the Late Cretaceous episode (see below), which would have overprinted any evidence of earlier cooling. Thus, it seems likely that all five samples from the Cango Inlier (and hence probably the entire block) underwent major cooling which began in the interval 145-130 Ma. 


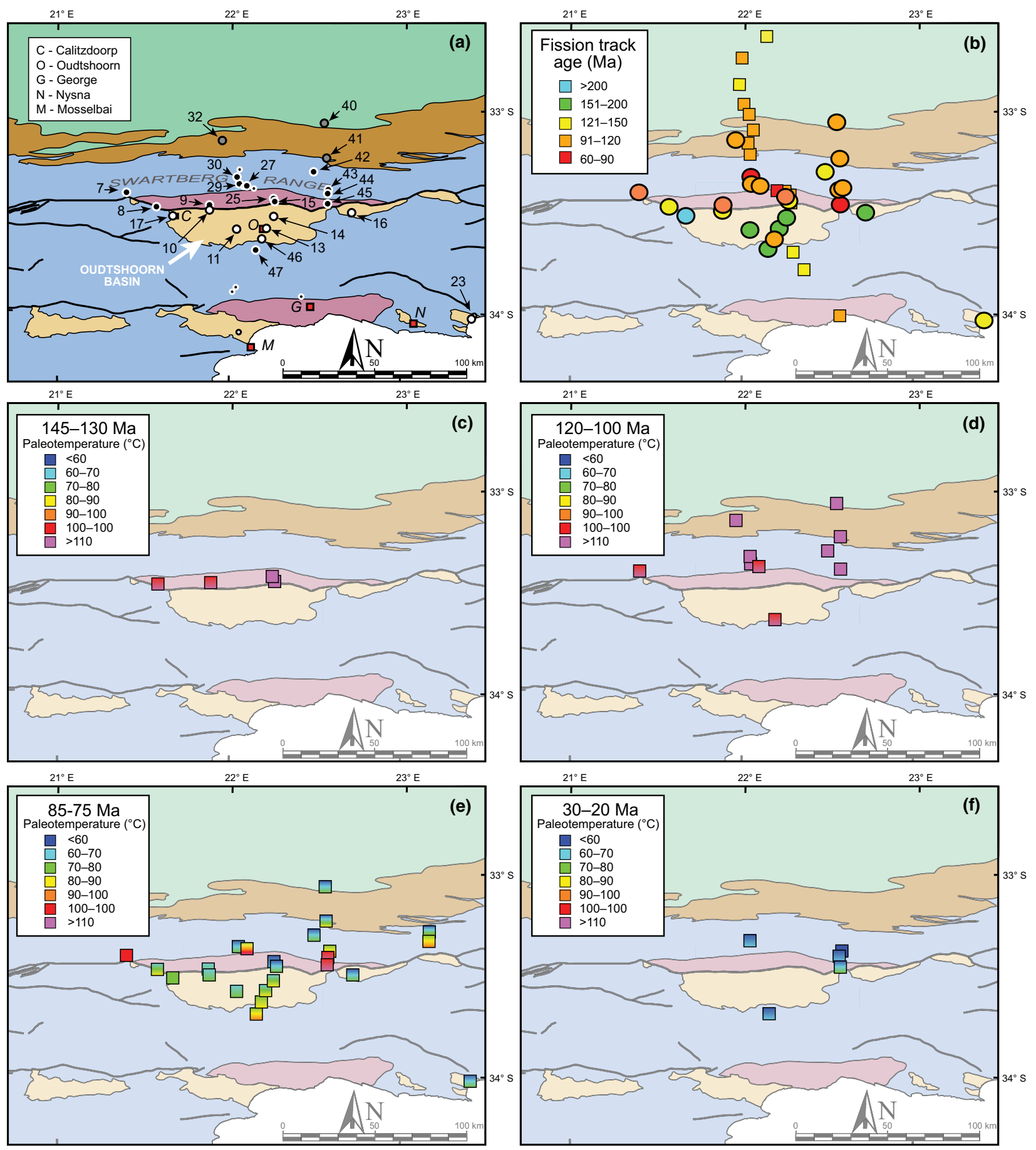

Fig. 10. Locations (a), apatite fission track ages (b) and paleotemperatures in four paleo-thermal episodes (c-f) for samples in and around the Oudtshoorn Basin (see Fig. 4 for location). In (b), fission track ages from this study are shown as circles while those from Tinker et al. (2008a) are shown as squares. Values from the two studies are similar, but results from this study in samples from Uitenhage Group in the Oudtshoorn Basin show older ages, highlighting the absence of Early Cretaceous effects in this region. Cooling which began between 145 and $130 \mathrm{Ma}$ (c) is restricted to samples from the Cango Inlier to the north of the Oudtshoorn Basin, while cooling which began between 120 and $100 \mathrm{Ma}(\mathrm{d})$ is largely restricted to North of the Cango Inlier. In contrast, Late Cretaceous cooling (e) is identified in all samples, although samples within the core of the Swartberg Range cooled from higher paleotemperatures in this event. Cenozoic cooling (f) is also largely restricted to these samples, suggesting differential Late Cenozoic cooling in this region.

Another paleo-thermal discontinuity in this region is evident in the Early-mid Cretaceous paleotemperatures (Fig. 10d). All but one of the samples located within and north of the Swartberg Range, including samples around the Great Escarpment near Beaufort West, cooled from $>110^{\circ} \mathrm{C}$ in the Early-mid Cretaceous episode, whereas this event is not identified in samples south of the northern boundary of the Cango Inlier. The single exception, 
sample GC1070-44 located within the range, cooled from $>110^{\circ} \mathrm{C}$ in the Late Cretaceous episode (similar to adjacent Cango inlier sample GC1070-45, above), which would have overprinted any evidence of earlier events, and it seems likely that this sample also underwent major cooling at 120-100 Ma. In contrast, none of the samples from the Cango Inlier show evidence of this episode. Only one sample analysed in this study from a location south of the northern boundary of the Cango Inlier shows evidence of Early-mid Cretaceous cooling (sample GC107046 from the southern margin of the Oudtshoorn Basin), and as noted earlier, this could reflect uncertainty in the precise depositional age.

While the delimitation of the effects of this episode is clear from Fig. 10d, published fission track ages around $100 \mathrm{Ma}$ in the southernmost samples analysed by Tinker et al. (2008a) (Fig. 10b) suggest that Early-mid Cretaceous cooling may also have affected 'basement' regions close to the coast to the south of the Oudtshoorn Basin. The lack of apatite in samples analysed from this region for this study precludes further comment on this aspect of the results.

Whereas these earlier events are restricted in their extent, evidence of Santonian-Campanian (85-75 Ma) cooling is found in outcrop samples across the entire area (Fig. 10e), although some significant offsets are still apparent in the results. Samples located in the Oudtshoorn Basin and regions south of the Swartberg Range cooled from paleotemperatures around $70-90^{\circ} \mathrm{C}$ in this episode, similar to samples around the Algoa and Gamtoos Basins (above). Similar Santonian-Campanian paleotemperatures around $70^{\circ} \mathrm{C}$ are also seen in samples to the north of the Swartberg Range, as well as one sample from the south coast (GC1070-23, Table 1, Fig 10e). Similar to the eastern region discussed above, samples from these regions show no evidence of Cenozoic cooling.

In contrast, samples GC1070-7, $-43,-44$ and -45 collected from canyons which dissect the Swartberg Range at elevations of $c a$. $500-800 \mathrm{~m}$ asl, show much higher Santonian-Campanian paleotemperatures, around $100^{\circ} \mathrm{C}$ or above, compared to samples at similar elevations to the north and south (Fig. 10e). Sample GC1070-29, collected from the road crossing the range at an elevation around $1500 \mathrm{~m}$, cooled from a lower temperature between $30^{\circ} \mathrm{C}$ and $70^{\circ} \mathrm{C}$ in this episode, while sample GC1070-30 from a slightly lower elevation cooled from between $75^{\circ} \mathrm{C}$ and $115^{\circ} \mathrm{C}$ at this time. When plotted against elevation, Santonian-Campanian paleotemperatures in these six samples, from locations within the core of the Swartberg Range, display a clear offset from those in samples at similar elevations immediately to the north and south, which are all consistent with a profile characterised by a geologically plausible paleogeothermal gradient of $30^{\circ} \mathrm{C} \mathrm{km}^{-1}$ (Fig. 11). This indicates that rocks within the Swartberg Range have been differentially exhumed with respect to surrounding regions subsequent to the onset of Santonian-Campanian cooling.
Further evidence of a tectonic offset of the Swartberg Range comes from the observation that the samples within the Swartberg Range which show higher Santonian-Campanian paleotemperatures also show significant Cenozoic cooling, with the four samples listed above all consistent with cooling from Cenozoic (30-20 Ma) paleotemperatures between $40^{\circ} \mathrm{C}$ and $60^{\circ} \mathrm{C}$ (Table 1 , Fig. 10f). Of other samples from the region shown in Fig. 10 only GC1070-47 shows any evidence of Cenozoic cooling. This may indicate that Cenozoic cooling was more widespread, but could alternatively relate to local effects around the location of this sample within a region of more pronounced relief at the southern margin of the basin.

In summary, the region shown in Fig. 10, spanning the Oudtshoorn Basin, the Swartberg Range and the Karoo Basin immediately to the north, displays a series of episodes of cooling which are restricted in one way or another to discrete tectonic blocks. The individual cooling episodes are restricted by apparently sharp boundaries, so a major proportion of the cooling in each episode must have been due to exhumation. A complex evolution of this region can therefore be defined (Fig. 12). In the Early Cretaceous, beginning some time between 145 and $130 \mathrm{Ma}$, as rifting and separation was taking place along the southern margin of Africa, and the Oudtshoorn Basin was subsiding and filling, the Cango Inlier was uplifted and eroded. This event could be explained in terms of footwall uplift, or perhaps by transpressional reactivation of a discrete segment in the footwall of the developing basin. Sometime later, between 120 and $100 \mathrm{Ma}$, the region to the north of the Cango Inlier was uplifted and eroded, while the region to the south presumably continued to subside, or at least was not exhumed to a similar degree. Following further burial, which may have extended to the north as indicated in Fig. 12, the region underwent a further phase of exhumation which began between 85 and $75 \mathrm{Ma}$, and the Swartberg Range has been exhumed by a greater amount than surrounding areas since that time. The Swartberg Range also underwent Cenozoic cooling (beginning between 30 and $20 \mathrm{Ma}$ ) which is not seen in samples to the north and south of the Range (except for the possibly anomalous sample GC1070-47, as discussed above). Since Santonian-Campanian paleotemperatures show a general increase from east to west across the region (Fig. 10e), we suggest the most likely scenario is that Santonian-Campanian exhumation was relatively uniform across the whole region in Fig. 10 while the Swartberg Range was differentially exhumed in the Cenozoic. Incision of valleys through the Range during Cenozoic uplift then led to exposure of samples within the Range that were hotter during the Late Cretaceous event than those at similar elevations today to the north and south of the Range. This interpretation thus explains the offsets in both Late Cretaceous and Cenozoic paleotemperatures in a single episode. 


\section{Great Escarpment around Beaufort West}

Three episodes of cooling are consistently defined in the AFTA data from samples around Beaufort West spanning the Great Escarpment. As shown in Fig. 13, Early-mid Cretaceous paleotemperatures in all samples were $>115^{\circ} \mathrm{C}$ (and $>140^{\circ} \mathrm{C}$ in some, reflecting the higher than usual Cl contents in many of the Karoo Supergroup apatites). Santonian-Campanian paleotemperatures are lower, around $80-120^{\circ} \mathrm{C}$ while Cenozoic values are typically around 50 $75^{\circ} \mathrm{C}$. For both these later events, paleotemperatures show only a minor increase with depth below the top of the Great Escarpment, but both datasets can be described by a paleogeothermal gradient of $c a .30^{\circ} \mathrm{C} \mathrm{km}^{-1}$ (as suggested by the Swartberg data in Fig. 11). Assuming a paleo-surface temperature of $25^{\circ} \mathrm{C}$, the $45^{\circ} \mathrm{C}$ intercept of the Cenozoic paleotemperature profile at the top of the escarpment suggests around $700 \mathrm{~m}$ of eroded section since the onset of Cenozoic cooling, while the $80^{\circ} \mathrm{C}$ intercept of the Santonian-Cenomanian profile suggests a value of $1800 \mathrm{~m}$.

We emphasise that such calculations are subject to considerable uncertainty, and are best regarded as providing only general indications of amounts of former cover. While Fig. 13 shows that Cenozoic and Late Cretaceous paleogeothermal gradients much higher than $30^{\circ} \mathrm{C} \mathrm{km}^{-1}$ are not allowed, a wide range of alternatives could be invoked, and possible nonlinearity in paleotemperature profiles through the former cover due to differences in thermal conductivity provide further uncertainty (Green \& Duddy, 2012). Surface temperature provides further uncertainty (a change in surface temperature of $10^{\circ} \mathrm{C}$, using a paleogeothermal gradient of $30^{\circ} \mathrm{C} \mathrm{km}^{-1}$ is equivalent to a difference of $333 \mathrm{~m}$ in the amount of removed section). Although these uncertainties propagate directly to estimates of eroded section, they do not significantly affect the principal conclusion that a significant amount of section has been eroded from the Great Escarpment since the onset of Late Cretaceous denudation. Furthermore, because all samples were totally annealed prior to Early Cretaceous cooling, the paleogeothermal gradient in that episode cannot be constrained, and it is possible that this event may have been characterised by a significantly elevated basal heat flow. In this case, the amount of additional section present when cooling began in this episode may have been close to that removed since the Late Cretaceous event, or possibly even less.

The $c a .1800 \mathrm{~m}$ of additional section required to explain the Late Cretaceous paleotemperatures is broadly consistent with the value of $1350 \mathrm{~m}$ of additional section present at the location of the Monastery kimberlite prior to the onset of Late Cretaceous denudation estimated by Hanson et al. (2009) based on kimberlite pipe morphology, bearing in mind possible uncertainties of hundreds of metres in both methods. Similarly, the value of $700 \mathrm{~m}$ for the amount of Cenozoic denudation agrees well with

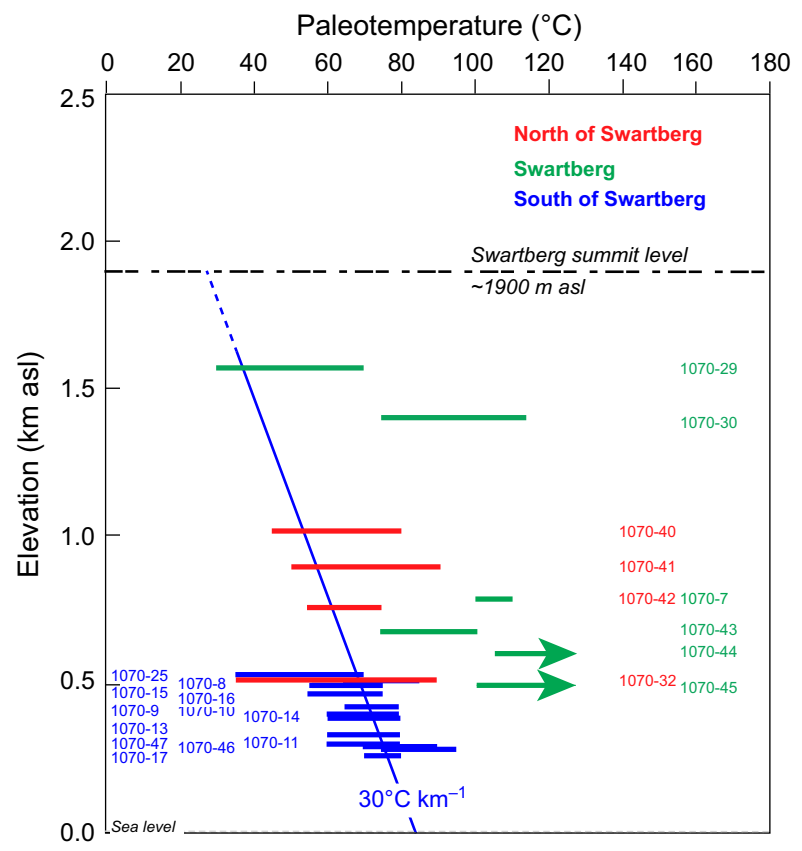

Fig. 11. Santonian-Campanian (85-75 Ma) paleotemperatures vs. elevation in samples from locations in and around the Swartberg Range. Samples from north and south of the range plot on a profile characterised by a gradient of $c a .30^{\circ} \mathrm{C} \mathrm{km}^{-1}$, whereas paleotemperatures in samples from locations within the core of the Swartberg Range plot above this profile. This suggests that the range has been undergone a greater degree of post-Santonian-Campanian cooling compared to neighbouring regions.

the value of 500-800 m (adjusted to our preferred values of surface temperature and thermal gradient, as discussed below) indicated by the (U-Th)/He data of Stanley et al. (2013) from kimberlites to the north of our samples (Fig. 2).

The question inevitably arises of how the events defined in samples from around the Great Escarpment at Beaufort West compare to those in and around the Swartberg Range illustrated in Fig. 12, particularly in relation to the magnitude of Cenozoic cooling. As no samples were collected between the two regions, it is difficult to speculate on this question at present. In samples such as GC1070-32, -40, -41 and -42, from the more subdued terrain to the north of the Swartberg Range, AFTA data show no evidence of any definite Cenozoic cooling (Table 1), although paleotemperatures up to $c a \cdot 50^{\circ} \mathrm{C}$ might be allowed within the resolution of the data. Results in these four samples are all consistent with CampanianSantonian paleotemperatures in the range $55^{\circ} \mathrm{C}$ and $75^{\circ} \mathrm{C}$, similar to Cenozoic values in samples from within the Swartberg Range and around the Great Escarpment, while Santonian-Campanian paleotemperatures in both these areas are much higher. These observations consistently lead to the conclusion that both the Swartberg Range and the region around the Great Escarpment have been exhumed to a greater degree than surrounding regions in the last $30 \mathrm{Myr}$. 

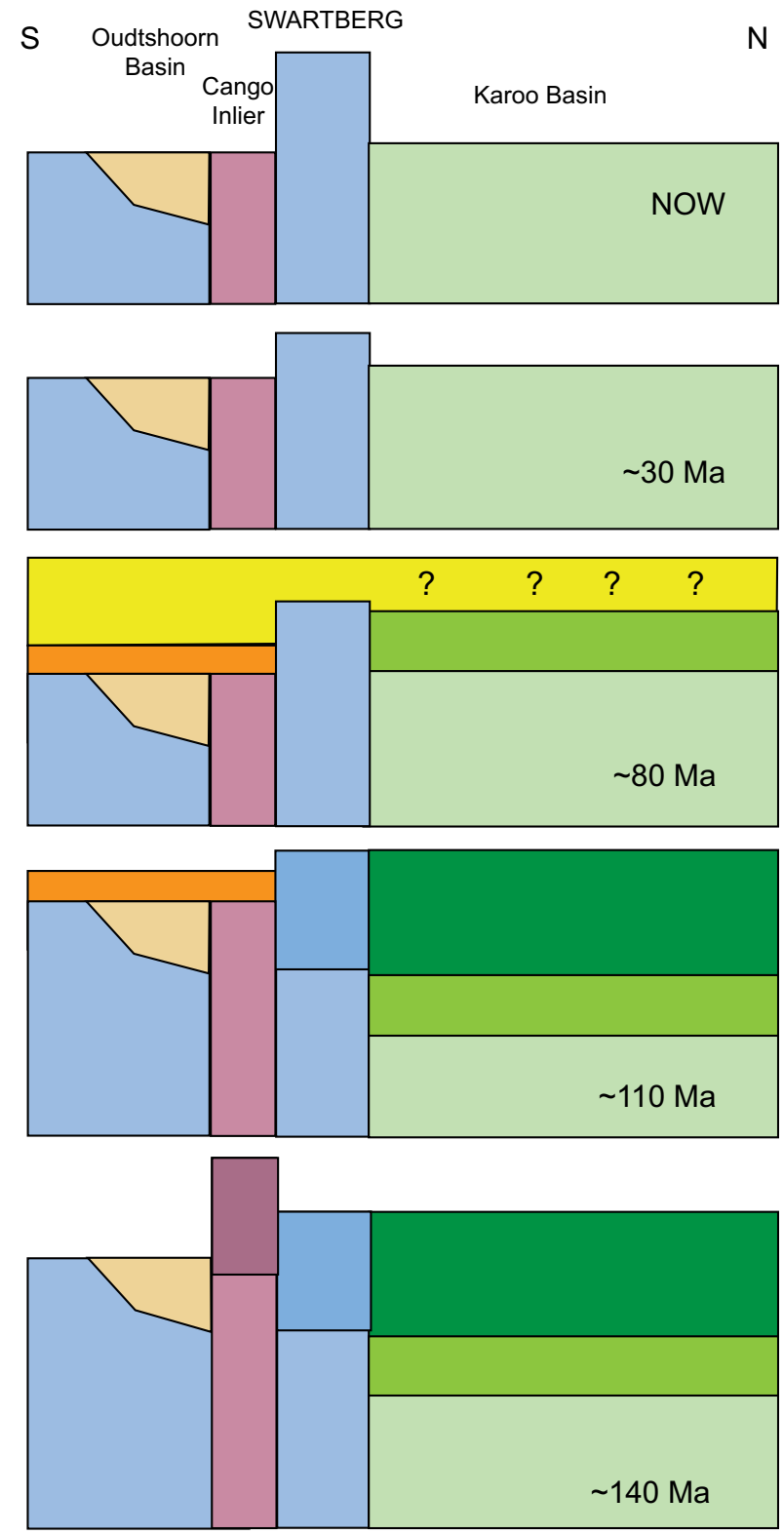

Fig. 12. Highly schematic north-south section across the Swartberg Range and the Oudtshoorn Basin, illustrating the Mesozoic and Cenozoic development (not to scale). At some time between 145 and $130 \mathrm{Ma}$, compressional forces led to uplift and erosion of the Cango Inlier, while development of the Oudtshoorn Basin was initiated. Between 120 and $100 \mathrm{Ma}$, the Karoo Basin and Swartberg Range were uplifted and eroded (darker shades indicate material removed during exhumation), adding to the preserved Late Jurassic to Early Cretaceous basin fill (orange). Prior to $80 \mathrm{Ma}$, Uitenhage Group sediments within the Oudtshoorn Basin were buried by an additional $c a .1 .5 \mathrm{~km}$ of section (yellow), which also extended over basin margins. This additional section may also have extended further north, as shown, or alternatively a thicker Karoo cover was present in this region. Late Cretaceous denudation post- $80 \mathrm{Ma}$ led to removal of this cover and older rocks to the north. By $30 \mathrm{Ma}$, the region was probably reduced to low relief. Cenozoic tectonics led to reactivation of the Swartberg Range and incision of rivers cutting through the range caused Cenozoic cooling identified from AFTA data in samples from within the range.

\section{Southwest Cape}

Samples from two basement samples in the southwest Cape region (GC1070-1, -5) show a similar style of thermal history to that defined for samples around the Great Escarpment, above, cooling from $>105^{\circ} \mathrm{C}$ or above in the Early-mid Cretaceous (120-100 Ma) episode, then from around $80-100^{\circ} \mathrm{C}$ in the Santonian-Campanian (85$75 \mathrm{Ma}$ ) episode and finally from $c a .50^{\circ} \mathrm{C}$ to $60^{\circ} \mathrm{C}$ in the Oligocene-early Miocene (30-20 Ma) episode (Table 1). Uitenhage Group sandstone samples from this region, GC1070-2, -3, -4 and -6, all show consistent evidence of Late Cretaceous cooling from around $90^{\circ} \mathrm{C}$, while sample GC1070-2 also shows Early Cretaceous cooling from $>125^{\circ} \mathrm{C}$. Samples GC1070-2, -4 and -6 also show Cenozoic cooling from $50^{\circ} \mathrm{C}$ to $60^{\circ} \mathrm{C}$ (Table 1). Late Cretaceous paleotemperatures around $80-100^{\circ} \mathrm{C}$ in all three Uitenhage Group samples in this region (plus the Early to mid-Cretaceous event in sample GC1070-2) clearly indicate that these sandstones were more deeply buried after deposition. Similar paleotemperatures in both basement and overlying sedimentary rocks in two Cretaceous episodes again suggests it is likely that the whole region underwent burial prior to the onset of cooling (exhumation) in these events.

Cenozoic cooling is identified in AFTA data in all six samples from this region, which were collected from elevations only $c a$. 200-300 m asl. Again assuming a paleogeothermal gradient of $30^{\circ} \mathrm{C} \mathrm{km}^{-1}$ and a paleo-surface temperature of $25^{\circ} \mathrm{C}$, the observed Oligocene-early Miocene paleotemperatures around $60^{\circ} \mathrm{C}$ are equivalent to burial by $c a .1 .2 \mathrm{~km}$ of additional section. With surrounding peaks reaching elevations of $1500 \mathrm{~m}$, the observed Cenozoic cooling in these samples could be accounted for by incision of the present-day relief below a formerly lowrelief surface approximately corresponding to present-day summit levels, following Cenozoic uplift of this surface from elevations close to sea level. However, more data are required to test this hypothesis more rigorously.

\section{Algoa and Gamtoos Basins and surrounding regions}

Samples are available over only a very limited range of elevations in this region, and provide no insight into paleogeothermal gradients. For a paleogeothermal gradient of $30^{\circ} \mathrm{C} \mathrm{km}^{-1}$ and a surface temperature of $25^{\circ} \mathrm{C}$, Santonian-Campanian paleotemperatures of $60-80^{\circ} \mathrm{C}$ in rocks now at outcrop in the central region across the Gamtoos and Algoa Basins are equivalent to a former cover of 1.2$1.8 \mathrm{~km}$ (but note comments above in relation to uncertainties in such calculations). This cover must have been deposited after deposition of the youngest preserved sedimentary units (?Valanginian; Shone, 2009) and prior to the onset of exhumation between 85 and $75 \mathrm{Ma}$.

Further constraint on the timeframe of denudation is provided by the presence in the southeast of South Africa 


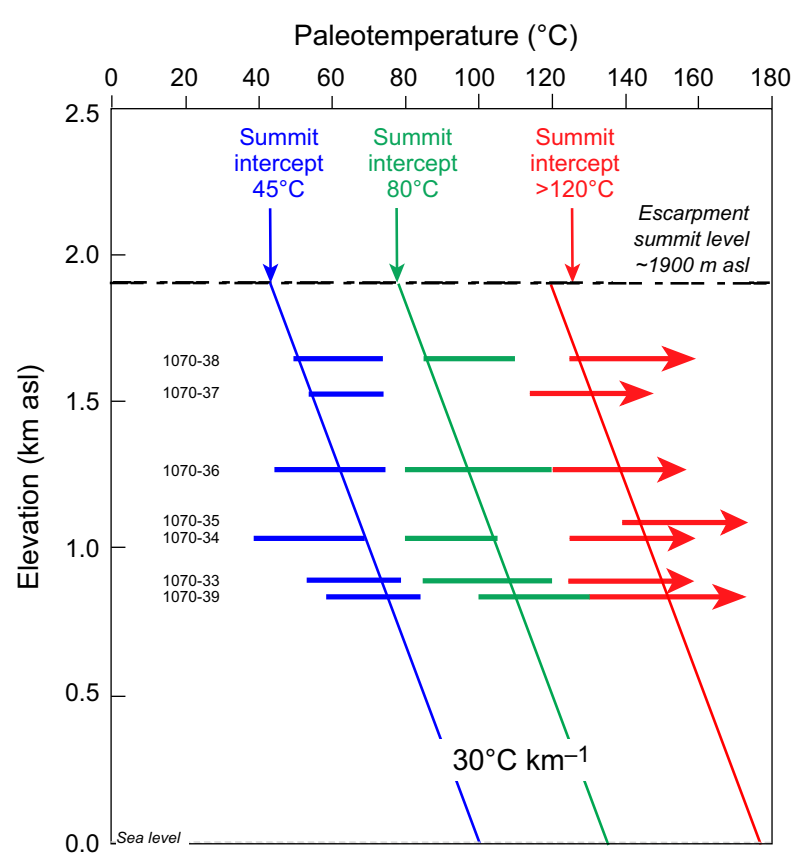

Fig. 13. Early-mid Cretaceous (red), Late Cretaceous (green) and Cenozoic (blue) paleotemperature profiles in samples from around the Great Escarpment. These results suggest significant denudation has occurred in the three cooling episodes.

of a well-defined regional marine erosional surface, which is overlain by marine limestones of Maastrichtian and Eocene age around Needs Camp (Roberts et al., 2009; Shone, 2009). The two samples from the Karoo sequence were collected close to the western extension of this surface. The phase of denudation defined in this region which began between 85 and $75 \mathrm{Ma}$, in which up to $1.5 \mathrm{~km}$ of section was removed, must therefore have been complete by late Maastrichtian times when the marine limestones were deposited on the erosion surface. AFTA data in samples from this region provide no evidence of Cenozoic cooling, suggesting that denudation of this region following development of the regional erosion surface has been only minor. This is consistent with preservation of the sedimentary remnants discussed above, and also with recent studies of terraces of the Sundays River (Erlanger et al., 2012) which suggest very low rates of uplift during Pliocene-Recent times.

\section{WHAT WAS THE NATURE AND EXTENT OF THE FORMER COVER REMOVED DURING LATE CRETACEOUS EXHUMATION?}

Definition of Late Cretaceous paleotemperatures of 60 $80^{\circ} \mathrm{C}$ or more in samples of Uitenhage Group sediments and underlying basement, indicating that these regions were buried by $c a .1 .5 \mathrm{~km}$ or more of younger cover prior to the onset of Late Cretaceous exhumation, raises ques- tions regarding the nature and origin of this former cover, as well as its former extent. A major contribution to this cover in the Mesozoic basins across the south of the region may have been erosional detritus from the region north of the Cango Inlier, which was uplifted and eroded in the Early-mid Cretaceous episode. A further contribution to this cover may have been provided by post-Drakensberg volcanism. A wide spread of chlorine contents in apatites from Uitenhage Group sandstones (Fig. 14) is diagnostic of a volcanogenic source for these grains, in contrast to samples from Paleozoic units which are dominated by F-rich grains more typical of a basement provenance (Green \& Duddy, 2012).

Whatever the origin of the former cover, post-rift subsidence and burial might be expected following Late Jurassic-Early Cretaceous rifting, in which case post-rift sediments should have extended considerably beyond the limits of the rift. The relatively uniform Late Cretaceous paleotemperatures across most of the region, in samples of both basin fill and underlying basement, show that the preserved Uitenhage Group sequences represent only a small erosional remnant of an originally much thicker Cretaceous cover that had developed across much of the southern Cape region by the time that exhumation began in the Santonian-Campanian. Our results are therefore consistent with the expected post-rift burial of a wide region prior to the onset of Late Cretaceous exhumation.

\section{CENOZOIC DENUDATION ALONG THE SOUTHERN AFRICA MARGIN}

Our results suggest that significant denudation has occurred in the more mountainous parts of the study area within the last $c a$. $30 \mathrm{Myr}$. Cenozoic paleotemperatures in samples from the SW Cape (Fig. 8e) are relatively uniform and could be explained by incision of the present-day relief below an uplifted low-relief erosion surface represented by present-day summits. In contrast, results from the Swartberg Range suggest that this region has been differentially exhumed in contrast to surrounding regions, which resulted in exposure of samples within the core of the Swartberg Range which cooled from higher temperatures in the Late Cretaceous episode compared to samples immediately to the north and south of the Range. Definition of significant Cenozoic cooling in samples such as GC1070-7, -43, -44 and -45 , which were collected in canyons that cut through the Swartberg range by rivers now at local base level suggests that these canyons were cut as a result of Cenozoic uplift of the range above surrounding regions.

In a recent study based on erosion rates derived from cosmogenic nuclides, Scharf et al. (2013) suggested that the Swartberg Range and similar landforms were longlived resistant features, with their modern topography reflecting the resistant nature of the predominantly quartzite lithologies of which they are composed. However, the low erosion rates measured by Scharf et al. (2013) are 
only relevant to the last million years or so. Despite the resistant nature of the rocks, the erosive power of the rivers which dissect these ranges was clearly sufficient to cut through them at some time in the past when erosion was stronger, and the evidence of differential Cenozoic exhumation of rocks in the Swartberg Range presented here suggests that this took place as a result of differential uplift of the ranges which began between 30 and $20 \mathrm{Ma}$.

Our results also define considerable Cenozoic cooling in samples from the Great Escarpment (Fig. 8f). Some previous studies have interpreted this feature as a longlived feature of the landscape, having fundamental significance in terms of the post-break up development of the region (see discussion in Green et al., 2013). But the results presented here show that the surface defining the present-day Great Escarpment lay beneath a significant thickness of rock until at least $30 \mathrm{Ma}$, and the present form must therefore represent the end-product of erosion since the onset of denudation between 30 and $20 \mathrm{Ma}$. Kempf (2010) reached a similar conclusion regarding the Great Escarpment of Namibia based on geomorphological considerations.

Evidence of Cenozoic uplift of this part of South Africa has been reported by Roberts \& White (2010), based on definition of gravity anomalies reflecting regions of mantle upwelling combined with analysis of river profiles, interpreted to indicate $\mathrm{km}$-scale uplift of an elongated dome along the southern margin of Africa more or less spanning our study region. With the analysis of river profiles by Roberts \& White (2010) suggesting initiation of uplift at ca. $30 \mathrm{Ma}$, the coincidence with the timing of Cenozoic exhumation reported here provides strong support for the possibility of significant uplift and erosion within the last $30 \mathrm{Myr}$ in this region.

In contrast, AFTA data from the Algoa and Gamtoos Basins and surrounding regions around Port Elizabeth shows no evidence of any significant amount of Cenozoic denudation. This is consistent with independent evidence from river terraces as discussed earlier. This observation is important in terms of the outcome of this study because some workers (e.g. Gunnell et al., 2003; Redfield, 2010) have suggested that evidence for late Cenozoic cooling from AFT data can be explained as an artefact of inaccurate fission track annealing algorithms. Although this suggestion has been discounted by Green et al. (2011, 2013) and Green \& Duddy (2012), the absence of Cenozoic cooling in many of the samples in this study provides a direct demonstration that in those samples in which the data do require Cenozoic cooling, this cannot be explained as an annealing model artefact.

\section{COMPARISON WITH PREVIOUS THERMAL HISTORY STUDIES}

Extensive AFT studies across southern Africa over the last 25 years (Brown et al., 1990, 1998, 2002, 2014; Gallagher \& Brown, 1999a,b; Raab et al., 2002, 2005; Kounov et al., 2008, 2009; Tinker et al., 2008a) have revealed evidence of major (km-scale) Cretaceous denudation across a wide region. Brown et al. (2014) presented a modern synthesis of previous studies (predominantly focussed on the Namibia margin) and interpreted the results in terms of a two major periods of cooling; an early Cretaceous phase focussed along the margin related to rifting and opening of the South Atlantic and a more regional Late Cretaceous phase due to reactivation of structures resulting from stresses related to changes in plate motion.

More directly relevant to this study, Tinker et al. (2008a) reported AFT data in outcrop samples collected along a north-south transect (locations shown in Fig. 8a), crossing the coastal plain, the Great Escarpment and the elevated inland region to a point $c a .500 \mathrm{~km}$ from the coast, within the Karoo Basin. Brown et al. (1990) also reported data from the southwest Cape area, but their interpretations were less rigorous and we focus on the results from Tinker et al. (2008a) here. Tinker et al. (2008a) analysed samples of the Paleozoic Cape Supergroup and older (Pre-Cape) units in the south, and various Permian and Triassic units of the Karoo Supergroup in the north of their transect. The similarity of data in outcrop samples from this study to those from previous studies is highlighted in Fig. 6. Tinker et al. (2008a) based quantitative conclusions on data in samples from three boreholes at locations south of the Great Escarpment (Fig. 2), and interpreted their results as defining a dominant phase of accelerated denudation in the Late Cretaceous, in the interval 100-80 Ma. In addition, Tinker et al. (2008a) also reported tentative evidence of Early Cretaceous (140-120 Ma) cooling from results in the QU $1 / 65$ borehole located to the north of the Escarpment (Fig. 2).

The two phases of cooling, 140-120 and 100-80 Ma, defined by Tinker et al. (2008a) are broadly consistent with the two episodes defined in this study beginning in the intervals $120-100$ and $85-75 \mathrm{Ma}$, particularly as the timing constraints from Tinker et al. (2008a) were derived within a framework involving monotonic cooling, which could lead to a slightly earlier timing compared to the episodic framework employed here. Overall, the similarity between the various datasets in Fig. 6 indicates that Santonian-Campanian cooling affected a wide region, with the results in Fig. 8e suggesting that it probably encompassed the entire region shown in Fig. 2. Tentative definition of Early Cretaceous cooling in the northernmost borehole of the four analysed by Tinker et al. (2008a) is also consistent with results presented here, although we note that this contradicts the synthesis presented by Brown et al. (2014) which involves Early Cretaceous cooling focussed towards coastal locations. The results presented here suggest a more complex evolution that the simple model presented by Brown et al. (2014).

Tinker et al. (2008a) attributed Late Cretaceous cooling to denudational removal of a once much thicker Karoo sequence extending in time to the Late Jurassic Drakensberg (ca. $183 \mathrm{Ma})$ volcanics, usually regarded as the ter- 

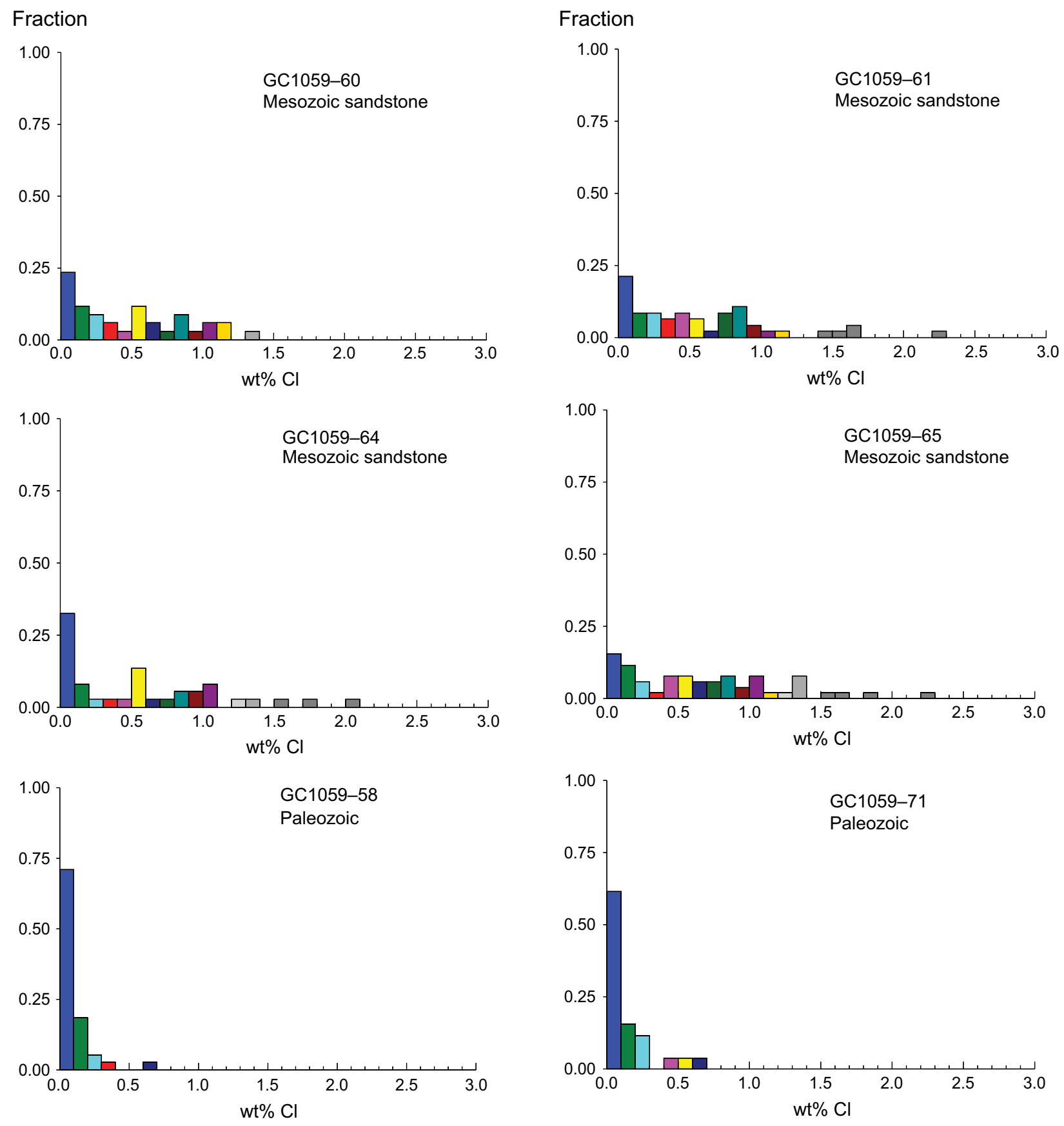

Fig. 14. Distributions of $\mathrm{wt} \% \mathrm{Cl}$ in apatites from various samples reveal key differences suggestive of different provenances. Samples of Paleozoic sandstones are characterised by an abundance of low $\mathrm{Cl}$ apatites $(<0.1 \mathrm{wt} \% \mathrm{Cl})$ with a small number of grains containing up to $c a .0 .5 \mathrm{wt} \% \mathrm{Cl}$. These are typical of sandstones derived from granitic provenance terrains. In contrast, apatites from Mesozoic sandstones of the Uitenhage Group show a much broader spread of chlorine contents up to $2 \mathrm{wt} \%$ or more, diagnostic of a volcanic origin (Green \& Duddy, 2012).

mination of the Karoo sequence. For samples of the Karoo Supergroup from the northern part of their transect, Tinker et al. (2008a) showed that the required thickness of former cover could be accommodated by the thicknesses of younger Karoo units preserved elsewhere in the basin. But at southerly locations on the transect studied by Tinker et al. (2008a), across the Cape Fold Belt, where AFT parameters in samples from outcrop are similar to those in Karoo samples to the north, a similar explanation is not possible because of the presence of the Late Jurassic to Early Cretaceous Uitenhage Group sediments (Fig. 2). Any units of the Karoo Basin sequence which were deposited in this region must have been removed prior to the onset of Uitenhage Group deposition. Therefore, Late Cretaceous (100-80 Ma) temperatures of $c a .100^{\circ} \mathrm{C}$ or more expressed in the fission track data of Tinker et al. (2008a) in outcropping samples of Cape Supergroup and basement across this region, which 
must have been at or close to the surface in the Late Jurassic to Early Cretaceous when deposition of the Uitenhage Group began, can only be explained by burial below a sedimentary cover post-dating the preserved units of the Uitenhage Group.

Our data also define significant amounts of Cenozoic cooling around the Great Escarpment, Swartberg and in the southwest Cape (Fig. 8f). Although Tinker et al. (2008a) downplayed the importance of Cenozoic cooling, their thermal history solutions for individual samples show more or less continuous cooling through the Cenozoic, suggesting that Cenozoic denudation was significant. Further evidence for Cenozoic cooling in this region was provided by Stanley et al. (2013) from apatite (U-Th)/He dating of samples from kimberlite pipes to the north of the samples analysed in this study (Fig. 2). They concluded that $c a$. $1.0-1.5 \mathrm{~km}$ of section was removed by Cenozoic denudation at the Markt pipe, decreasing to the south towards our sample locations. Significant Cenozoic cooling was only allowed within uncertainties for the southerly kimberlites and not definitely required by the data. However, because crater facies kimberlite is not preserved at the $74 \mathrm{Ma}$ Hebron kimberlite (attributed to 'diatremes facies' by Stanley et al., 2013), significant post-74 Ma erosion ( $>300 \mathrm{~m}$ according to the scheme of Stanley et al., 2013) has clearly taken place. The results of Stanley et al. (2013) suggest that a significant amount of regional Cenozoic denudation has occurred in this region, supporting our interpretations. Stanley et al. (2013) assumed a surface temperature of $20^{\circ} \mathrm{C}$ and a thermal gradient of $20^{\circ} \mathrm{C} \mathrm{km}^{-1}$, whereas using values of $25^{\circ} \mathrm{C}$ and $30^{\circ} \mathrm{C} \mathrm{km}^{-1}$ as adopted here the Cenozoic cooling in their data equates to between 500 and $800 \mathrm{~m}$ of removed section at the Markt kimberlite (cf. our estimates of $700 \mathrm{~m}$ removed from the Great Escarpment by Cenozoic denudation from Fig. 13, as discussed earlier).

\section{COMPARISON WITH THE OFFSHORE SEDIMENTARY RECORD}

The remnant sedimentary units of the Uitenhage Group onshore represent restricted portions of a depositional system that is more extensively developed offshore, with the whole system known as the Outeniqua Basin (e.g. Broad et al., 2009). Simplifying the regional framework somewhat, thick syn-rift (Late Jurassic - Early Cretaceous) deposits in a series of half grabens are truncated and overlain by post-rift sequences above a basin-wide mid-Aptian unconformity - the 13At1 horizon (Figs 15 and 16; Beckering Vinckers \& Jensen, 2005; Beckering Vinckers, 2007). A number of additional unconformities are present through this sequence. In the offshore Algoa Basin, Broad et al. (2009) document a phase of canyon incision in the Late Barremian or early Aptian (125$120 \mathrm{Ma})$ followed by infilling in Late Aptian to Albian times (ca. 115-100 Ma). The coincidence in timing between these events and the major Early to mid-Cretac- eous cooling episode documented onshore in this study, which began between 120 and $100 \mathrm{Ma}$, supports the interpretation that this cooling represents uplift and denudation of the onshore region, reflected in canyon incision in the adjacent offshore basin and subsequent infilling with erosional detritus from the uplifted hinterland.

A cross-section through the offshore Algoa Basin is shown in Fig. 16 (after Viljoen et al., 2010). Little imagination is required to see that deep erosion of this section, which shows tilted and truncated basement arches and adjacent extensional basins, would produce a situation very similar to the Oudtshoorn Basin and Swartberg region (although the Swartberg Range was accentuated during Cenozoic movements, as discussed earlier). The results of this study suggest that the offshore setting could provide a direct analogue for the present-day onshore region prior to the onset of exhumation, with the onshore region once having been covered by a much more extensive sedimentary cover similar to the present-day offshore region, prior to the onset of exhumation.

McMillan (2003) presented a foraminifera-based biostratigraphic synthesis of the Barremian to Maastrichtian sedimentary succession in seven offshore basins around southern Africa, and defined a number of synchronous unconformities. One of these, dated at around $c a$. 76.5 Ma (recognised as the 17At1 horizon in sequence stratigraphic studies summarised by Broad et al., 2009; also see Fig. 15) correlates closely with the 85-75 Ma timing for the onset of exhumation defined from AFTA in this study. Stevenson \& McMillan (2004) reported west-dipping, truncated Late Cretaceous (Albian to Santonian) sedimentary units of the Orange Basin overlain by Miocene units, and Paton et al. (2008) document a major erosional unconformity in the Orange Basin representing the interval 77.5-67 Ma. Both these unconformities also correlate with the Santonian-Campanian cooling episode, and are regarded, along with the 17At1 horizon, as reflecting the Santonian-Campanian uplift and denudation recognised in this study.

Tinker et al. (2008b) attempted a comparison of the amount of denudation defined by their AFT data onshore and the amount of sediment preserved in offshore basins. They reported a maximum in offshore sediment accumulation rate in the period 93-67 Ma which closely matches the timing of accelerated denudation onshore between 100 and $80 \mathrm{Ma}$ defined from their results, and is also consistent with onset of exhumation identified in this study (85-75 Ma). MacGregor (2012) has also recently drawn attention to this Late Cretaceous peak in accumulation rates offshore southern Africa and the link to denudation onshore. Braun et al. (2014) drew further attention to the correlation between offshore sediment thickness and Late Cretaceous denudation onshore.

Tinker et al. (2008a) calculated that the volume of sediment preserved offshore was equivalent to an average thickness of $860 \mathrm{~m}$ of denudation from their onshore 
source area, whereas they estimated an average total removal of $2.5-3.5 \mathrm{~km}$ of denudation onshore from their fission track data. In addressing possible explanations for this mis-match, one that they did not consider is the possibility of an increased Cretaceous paleogeothermal gradient (i.e. heat flow). Alternatively, since much of the material removed from the onshore is likely to have been sedimentary in nature, a nonlinear paleogeothermal profile as a result of relatively low conductivity sediments overlying high conductivity basement (Green \& Duddy, 2012) would require less burial to produce a given paleotemperature.

In addition, if much of what was eroded from the onshore region was the product of fragmental volcanism, as suggested earlier, the total amount of sediment that accumulated in offshore depocentres may have been much less than would be expected if the eroded material was derived from basement rocks. Macdonald et al. (2013) showed that whereas detrital zircons from the Late Cretaceous Ceduna delta sequence on the southern margin of Australia reveal a major component of derivation from Early Cretaceous volcanoclastic sediments from the onshore margins, the bulk of the Late Cretaceous basin fill was dominated by quartzose basement-derived material. Most of the volcanic material (including reactive minerals, rock fragments, volcanic glass etc.) was lost in transport, dissolved or deposited as clays further offshore. Thus, while deposition of a sedimentary cover of dominantly volcanoclastic material can produce the heating required to explain the AFT data, erosion, dissolution and transport of this material will produce a much smaller thickness of clastic sediment in proximal depocentres than might be otherwise expected.

\section{RELEVANCE TO THE POST-BREAKUP DEVELOPMENT OF PASSIVE MARGINS}

The results presented here from the southern margin of Africa define a history involving major post-breakup subsidence and burial, followed much later by kilometre-scale uplift and denudation. This style of history is radically different from current ideas regarding the development of the continental margins of southern Africa and rifted margins in general (Green et al., 2013). However, we have identified similar histories involving episodic postbreakup burial and later exhumation in recent studies on other continental margins (Green \& Duddy, 2010; Japsen et al., 2010, 2012a,b; Green et al., 2013). On the West Greenland margin, integration of AFTA and VR data with landscape evidence defines significant post-breakup burial and several subsequent episodes of uplift and denudation (Japsen et al., 2005, 2006). This is supported by the presence of post-breakup marine rocks at more than $1 \mathrm{~km}$ asl, providing direct evidence of post-breakup subsidence and burial prior to subsequent uplift. Later studies in East Greenland have indicated a similar history (Bonow et al., 2014; Japsen et al., 2014). Integration of
AFTA and landscape analysis on the Atlantic margin of Brazil (Japsen et al., 2012b) resulted in definition of a similar style of development, with post-breakup burial followed by exhumation which began between 80 and $75 \mathrm{Ma}$ (similar to this study), followed by further phases of exhumation-reburial-exhumation. In Brazil, the presence of marine post-breakup sedimentary rocks in the Araripe Plateau now at elevations around $600 \mathrm{~m}$ asl provides direct evidence of a similar history (Green et al., 2013). Late Cretaceous cooling from paleotemperatures between $60^{\circ} \mathrm{C}$ and $120^{\circ} \mathrm{C}$ from the Atlantic margin of Namibia, in outcrop samples overlain by Early Cretaceous Etendeka lavas and sandstones (Raab et al., 2002), also require post-rift burial by a $\mathrm{km}$-scale thickness of postEtendeka section which was removed during Late Cretaceous and later exhumation. Paton (2012) has also recently emphasised that the development of many passive margins was more complex than previously envisaged.

Green et al. (2013) suggested that histories involving episodic post-breakup subsidence/burial and later uplift and denudation, possibly in several episodes, are a general feature of EPCM development, and are reflected in the characteristic EPCM morphology. Japsen et al. (2012a) recently suggested a model for the development of EPCMs in which the margin subsides following breakup and is buried by post-rift sediments. An initial phase of uplift leads to removal of the sedimentary cover and denudation to regional base level (sea level) produces an area of low relative relief (a peneplain). This may be reburied prior to renewed uplift causing uncovering of the peneplain, which is then uplifted to $>1 \mathrm{~km}$ asl, leading to incision of river valleys and further denudation. Offshore the sedimentary units are tilted and truncated and perhaps overlain unconformably by units laid down during renewed subsidence.

In Southern Africa, evidence of this style of history is expressed by the offshore west coast unconformities correlating with onshore Late Cretaceous uplift and erosion discussed earlier. Complementary east-dipping Late Cretaceous units occur on the east coast in the Lebombo monocline (Shone, 2009) and although the precise stratigraphy is not as well defined as on the west coast, deposition may have extended here into the Maastrichtian. Burke \& Gunnell (2008) suggested that these opposed dipping Late Cretaceous units represent uniform uplift of the intervening continent at the end of the Cretaceous, but as mentioned above, stratigraphic evidence from the west coast suggests earlier uplift there.

McMillan (2003) suggests that the multiple unconformities recognised around the southern edge of Africa reveal a history of repeated tilting through the Late Cretaceous, involving 'repeated... east-west rolling motions' about an axis 'in the vicinity of East London', which he attributed to regional tectonic activity. Evidence of Cenomanian uplift and erosion on the east coast presented by Braun et al. (2014), coupled with results presented here indicating uplift of the west and south coasts in the Santonian-Campanian, plus the suggestion of end-Cretaceous 


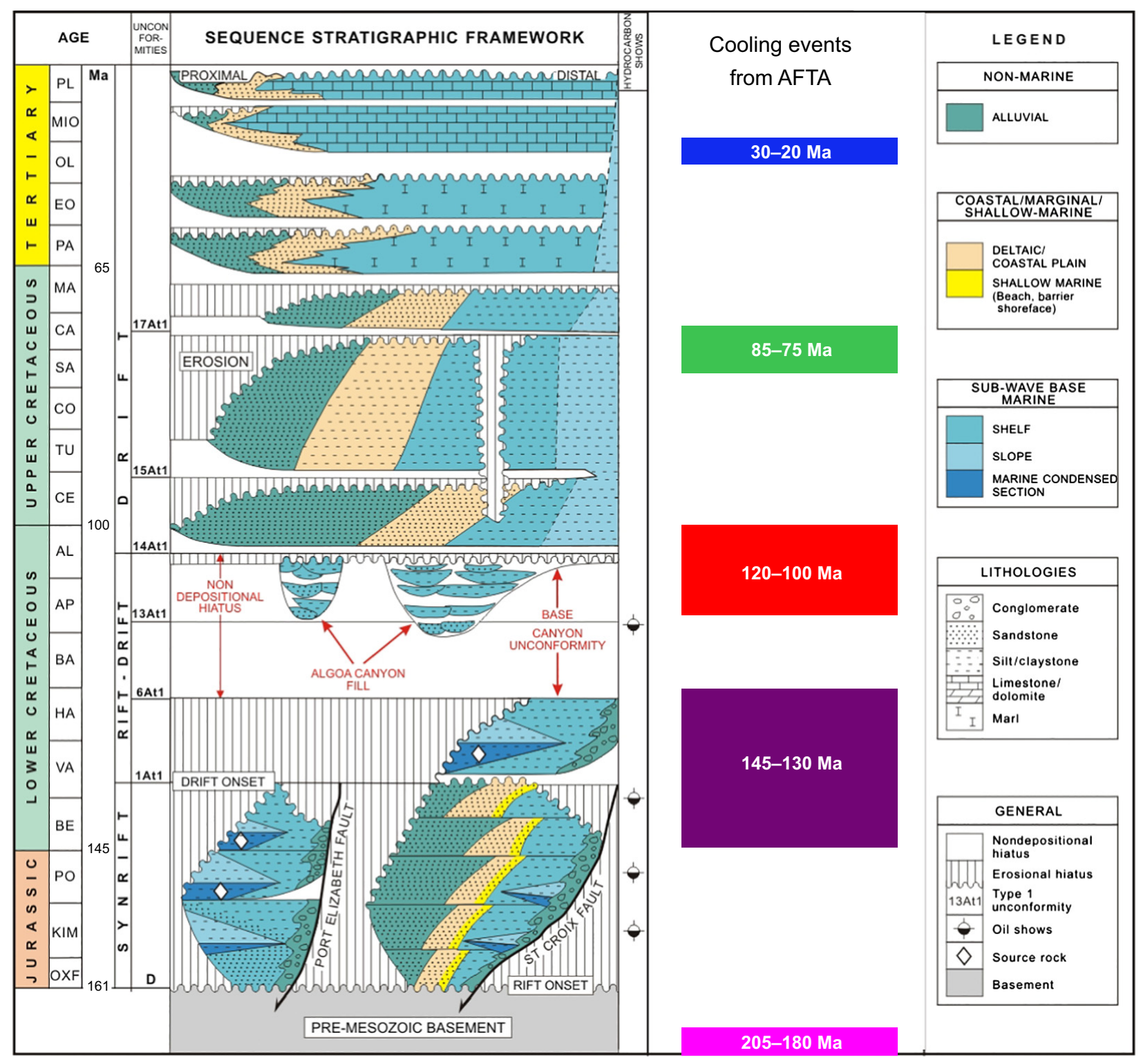

Fig. 15. Offshore Algoa Basin sequence stratigraphic framework (after Beckering Vinckers \& Jensen, 2005; Beckering Vinckers, 2007), also showing the regional cooling episodes defined in this study. The coincidence between these events and major unconformities offshore is clear, emphasising the tectonic origin of the events responsible for cooling.

uplift on the east coast from Burke \& Gunnell (2008), combine to support the idea of east-west rolling inferred by McMillan (2003), reflecting repeated tectonic tilting of the continent.

Green et al. (2013) reviewed past difficulties in reconciling evidence of Cretaceous exhumation from thermochronology with evidence of fairly recent uplift of modern-day topography (e.g. Ollier \& Pain, 1997; Partridge, 1998; Burke \& Gunnell, 2008). Some studies (e.g. Braun et al., 2014) explicitly identify Late Cretaceous exhumation with uplift of the plateau (without defining how or when this low-relief surface was formed). However, exhumation need not result in elevated topography. Many regions which have been subject to $\mathrm{km}$-scale denudation during the Cenozoic are now below sea level, most notably the Barents Sea (Green \& Duddy, 2010), demonstrating that exhumation does not lead to permanent uplift of land. With growing evidence from many regions for repeated positive and negative vertical motions at continental margins, the results of this study suggest that Late Cretaceous denudation resulted in a region of low relief that was then uplifted relatively recently, as suggested by King $(1967,1972)$, Partridge \& Maud (1987) and Burke \& Gunnell (2008), without significant denudation. Cenozoic uplift of this nature is illustrated by the presence of Maastrichtian and Eocene marine limestones at elevations of up to $375 \mathrm{~m}$ above present-day sea level at locations around East London such as Needs Camp (Dingle et al., 1983; Roberts et al., 2009; Shone, 2009). As noted earlier, results from the SW Cape would be consistent with incision of the present-day relief below a lowrelief landscape uplifted since $30 \mathrm{Ma}$. 

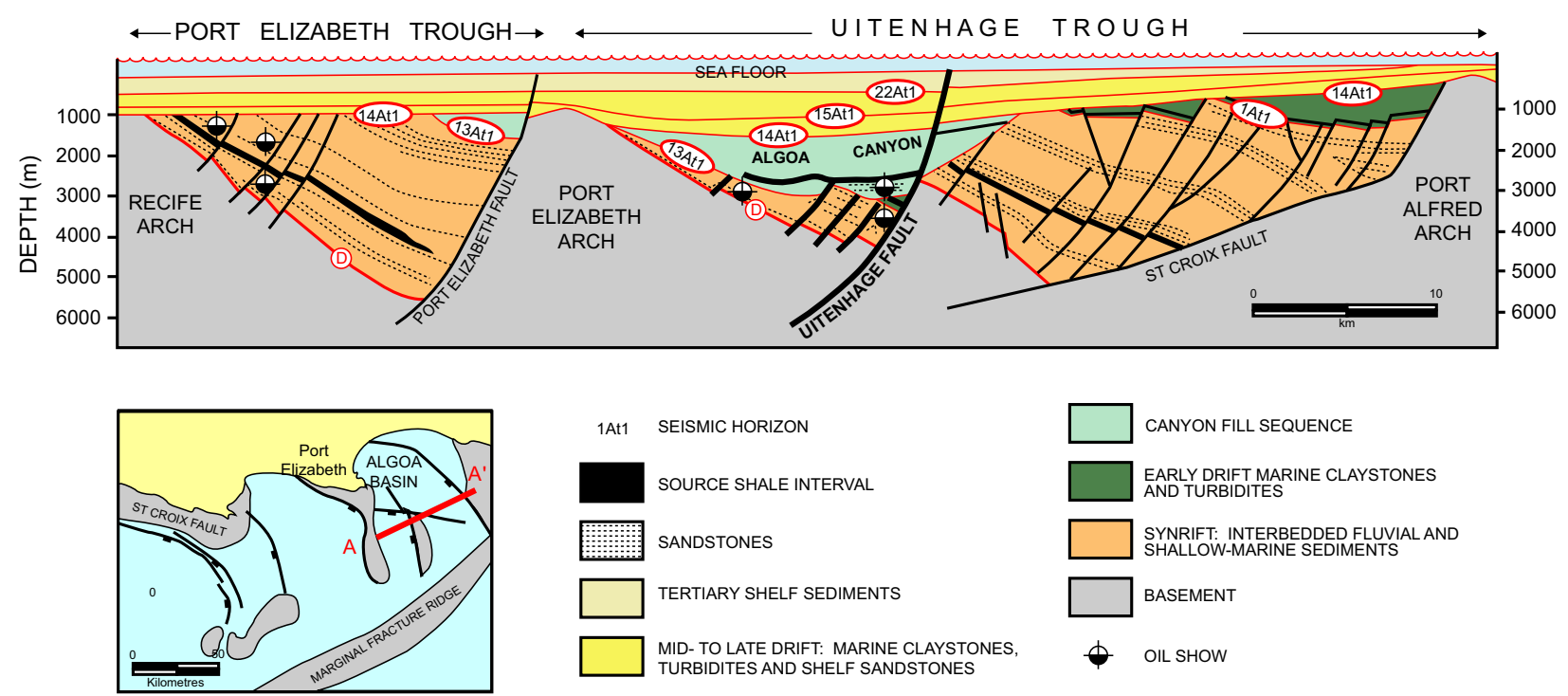

Fig. 16. Algoa Basin Structural framework (after Viljoen et al., 2010). The present-day setting of the Oudtshoorn Basin and Swartberg Range resembles a deeply eroded version of the basin and basement arch pairings in this section. Thus, it seems likely that this section provides an analogue for the present-day onshore region prior to the onset of Late Cretaceous exhumation. Unconformities 13 At1 etc. are defined in Fig. 15.

In summary, a range of observations suggest that the southern margin of Africa has undergone a series of positive and negative vertical movements through the Late Cretaceous and Cenozoic, during which $\mathrm{km}$-scale thicknesses of section were deposited and removed, similar to those reported on other continental margins by Green et al. (2013).

\section{MECHANISMS}

A wide variety of processes have been suggested for producing uplift of southern Africa and similar episodes of exhumation recognised from low temperature thermochronology in other regions. These include mantle dynamics (Lithgow-Bertelloni \& Silver, 1998), magmatic underplating (Brodie \& White, 1994), lithospheric delamination (Houseman et al., 1981), phase changes in the mantle (Simon \& Podladchikov, 2008), climate change (Molnar \& England, 1990) and lithospheric folding (Cloetingh \& Burov, 2011).

These concepts address only upward vertical movements in single episodes, and do not account for the observation that in many cases, such as that presented here as well as in Brazil (Japsen et al., 2012b), West Greenland (Japsen et al., 2005, 2006) and East Greenland (Japsen et al., 2014), both positive and negative vertical movements are involved (i.e. post-breakup subsidence and burial prior to the onset of uplift and erosion, often in multiple episodes). In this regard it is important to realise that the prior burial phase can only be defined from low temperature thermochronology by analysing samples where sedimentary cover is preserved, since ther- mochronology data can only define cooling episodes, and cannot independently reveal re-heating (see Green $e t$ al., 2013). Sadly, many thermochronology studies have been focussed in areas where sediment cover is lacking, while where cover remains its presence is often ignored (Green et al., 2013; Section 8.2).

An empirical observation that could provide key insight into the nature of the underlying processes is an apparent synchroneity over wide distances in the timing of periods of exhumation identified from AFTA data, which also show a temporal correlation with episodes of tectonism. Exhumation which began between 85 and $70 \mathrm{Ma}$ has also been recognised from AFTA to the north of this study area on the West African margin in Equatorial Guinea (Turner et al., 2008), while evidence of broadly synchronous cooling has also been reported from the west coast of South Africa (Gallagher \& Brown, 1999a,b) and Namibia (Raab et al., 2002, 2005). AFTA data from the Atlantic margin of Brazil (Japsen et al., 2012b) define a similar development as that for southern Africa presented here, with post-breakup burial followed by exhumation which began in the interval 80 and $75 \mathrm{Ma}$, while regional exhumation at a similar timing was also identified in $\mathrm{NE}$ Brazil by Harman et al. (1998). A major phase of Andean orogeny also occurred at this time (Cobbold et al., 2001, 2007).

Although the broad synchroneity between these episodes of exhumation on different continents may be dismissed as coincidence, a similar synchroneity of exhumation episodes has been identified around the North Atlantic and Arctic regions involving a number of discrete episodes through the Cenozoic (Green \& Duddy, 
2010; Japsen et al., 2010, 2014). In these studies, the events identified from AFTA are also recognised as defining regional unconformities along almost the entire NW European North Atlantic margin. We suggest that this regional synchroneity of episodes of exhumation, combined with the scale on which exhumation is observed, indicates that the underlying processes act on a plate scale, and are probably related in some way to transmission of stresses related to plate motions and reorganisations. Japsen et al. (2012a) suggested that lateral resistance to plate motion could be responsible, and pointed out that the synchroneity of regional exhumation episodes in South America and Africa, on opposite margins of two diverging plates, shows that the driving forces can transmit across the spreading axis, probably at great depth, e.g. in the asthenosphere.

\section{CONCLUSIONS}

New AFTA and VR data in surface samples of the Late Jurassic to Early Cretaceous Uitenhage Group and underlying basement rocks from the southern margin of Africa and of Karoo Supergroup around the Great Escarpment define a series of major regional cooling episodes. Given their regional extent it seems likely that cooling in these episodes primarily represents exhumation, although additional processes may be involved in some episodes.

Latest Triassic to Early Jurassic (205-180 Ma) cooling, seen dominantly in basement flanks to the Algoa and Gamtoos Basins, may have affected a wider region but in most places any effects have been overprinted by later events. Early Cretaceous (145-130 Ma) exhumation was limited largely to the Cango Inlier and probably reflects inversion of this block due to compression. Early to mid-Cretaceous (120-100 Ma) exhumation affected a wide region but its effects are cut off by the northern bounding fault to the Cango Inlier, suggesting major movement on this structure at this time. This event is reflected offshore by incision of canyons and subsequent delivery of erosional products to infill those canyons.

In contrast to these two structurally controlled episodes, Santonian-Campanian (85-75 Ma) exhumation is identified over the entire study area, showing a generally smooth pattern of variation over most of the region. Late Jurassic to Early Cretaceous rocks of the Uitenhage Group now at outcrop, together with underlying basement rocks, were buried sufficiently to heat these samples to around $65-75^{\circ} \mathrm{C}$ or higher prior to exhumation in this episode. The extent of the additional burial required to explain paleotemperatures in this episode is not clear, but our results show that the preserved Uitenhage Group sequences represent only a small erosional remnant of an originally much thicker Cretaceous cover, and it is possible that this former cover may have extended further north across the Karoo Basin, where this cooling event is more strongly expressed.

The final phase in the development of the present-day landscape of South Africa took place in the Cenozoic as a result of a denudation episode which began in the Oligocene - early Miocene (30-20 Ma). Results from the Swartberg Range suggest that this was differentially exhumed with respect to surrounding regions, while samples from the Great Escarpment show Cenozoic cooling from paleotemperatures around $60-70^{\circ} \mathrm{C}$. The Great Escarpment therefore has no relationship with continental break up, as is often supposed, and simply represents the result of denudation within the last $30 \mathrm{Myr}$.

Similar histories involving post-breakup subsidence and burial and much later uplift and erosion have been identified at a number of other EPCMs in recent years, and seem to be a common component in the development of the characteristic EPCM topography. This style of evolution is very different from conventional ideas of passive margin evolution. The results presented here suggest that it is time for a radical re-think of models for the post-rift development of continental margins.

\section{CONFLICT OF INTEREST}

There is no conflict of interest for any of the authors.

\section{ACKNOWLEDGEMENTS}

The authors would like to express their thanks to NewAge (African Global Energy) Ltd for funding sample collection and analyses, and for their permission to publish the results. Five reviewers helped to shape the final form of the paper. Particular thanks are due to Douglas Paton for helpful comments and support, to Christopher A.-L. Jackson for ongoing encouragement, and to Editor George Hilley for seeing the process through to completion.

\section{SUPPORTING INFORMATION}

Additional Supporting Information may be found in the online version of this article:

Data S1. Supplementary information.

\section{REFERENCES}

Amante, C. \& Eakins, B.W. (2009) ETOPO1 1 Arc-Minute Global Relief Model: Procedures, Data Sources and Analysis. NOAA Technical Memorandum NESDIS NGDC-24. 
National Geophysical Data Center, NOAA. doi:10.7289/ V5C8276M.

Barbarand, J., Carter, A., Wood, I. \& Hurford, A.J. (2003) Compositional and structural control of fission track annealing in apatite. Chem. Geol., 198, 107-137.

Bate, K.J. \& MALAN, J.A. (1992) Tectonostratigraphic evolution of the Algoa, Gamtoos and Pletmos Basins, offshore South Africa. In: Inversion Tectonics of the Cape Fold Belt, Karoo and Cretaceous Basins of Southern Africa (Ed. by M.J. de Wit \& I.G.D. Ransome), pp. 61-73. Balkema, Rotterdam.

Beckering Vinckers, J. (2007) Area D. Offshore Algoa Basin. Republic of South Africa 2007 Licence Round, pp. 60. Petroleum Agency SA, Capetown.

Beckering Vinckers, J. \& Jensen, T. (2005) Oil potential in the Algoa basin offshore South Africa. Poster. 18th World Petroleum Congress. South Africa.

Blenkinsop, T. \& Moore, A. (2013) Tectonic geomorphology of passive margins and continental hinterlands. In: Treatise on Geomorphology (Ed. by J.F. Shroder), vol. 5, pp. 71-92. Academic Press, San Diego.

Bonow, J.M., Japsen, P. \& Nielsen T.F.D. (2014) High-level landscapes along the margin of southern East Greenland - a record of tectonic uplift and incision after breakup in the NE Atlantic. Global Planet. Change, 116, 10-29.

Braun, J., Guillocheau, F., Robin, C., Baby, G. \& Jelsma, H. (2014) Rapid erosion of the Southern African Plateau as it climbs over a mantle superswell. F. Geophys. Res., 119, 60936112 .

Broad, D.S., Jungslager, E.H.A., Clachan, I.R. \& Roux, J. (2009) Offshore Mesozoic basins. In: The Geology of South Africa (Ed. by M.R. Johnson, C.R. Anhaesseur \& R.J. Thomas), Chapter 26, pp. 553-571. Council for Geoscience, Pretoria.

Brodie, J. \& White, N. (1994) Sedimentary basin inversion caused by igneous underplating: northwest European continental shelf. Geology, 22, 147-150.

Brown, R.W., Rust, D.J., Summerfield, M.A., Gleadow, A.J.W. \& DE WrT, M.C.J. (1990) An accelerated Cretaceous phase of accelerated erosion on the south-western margin of Africa: evidence from apatite fission track analysis and the offshore sedimentary record. Nucl. Tracks Radiat. Meas., 17, 339-350.

Brown, R.W., K., Gleadow, A.J.W. \& Summerfield, M.A. (1998) Morphotectonic evolution of the South Atlantic margins of Africa and South America. In: Geomorphology and Global Tectonics (Ed. by M.A. Summerfield), pp. 255-281. Wiley, Chichester.

Brown, R.W., Summerfield, M.A. \& Gleadow, A.J.W. (2002) Denudational history along a transect across the Drakensberg Escarpment of southern Africa derived from apatite fission track thermochronology. F. Geophys. Res., 107, 2350.

Brown, R.W., Summerfield, M.A., Gleadow, A.J.W., Gallagher, K., Carter, A., Beucher, R. \& Wildman, M. (2014) Intracontinental deformation in southern Africa during the Late Cretaceous. F. Afr. Earth Sc., 100, 20-41.

Burke, K. \& Gunnell, Y. (2008) The Africa Erosion Surface: A Continental-Scale Synthesis of Geomorphology, Tectonics and Environmental Change Over the Past 180 Million Years, pp. 201. Geological Society of America, Memoirs.

Burnham, A.K. \& Sweeney, J.J. (1989) A chemical kinetic model of vitrinite reflectance maturation. Geochim. Cosmochim. Acta, 53, 2649-2657.
Carlson, W.D., Donelick, R.A. \& Ketcham, R.A. (1999) Variability of apatite fission-track annealing kinetics: I. Experimental results. Am. Mineral., 84, 1213-1223.

Catuneanu, O., Wopfner, H., Eriksson, P.G., Cairncross, B., Rubidge, B.S., Smith, R.M.H. \& Hancox, P.J. (2005) The Karoo basins of south-central Africa. 7. Afr. Earth Sc., 43, 211-253.

Cloetingh, S. \& Burov, E. (2011) Lithospheric folding and sedimentary basin evolution: a review and analysis of formation mechanisms. Basin Res., 23, 257-290.

Cobbold, P.R., Meisling, K.E. \& Mount, V.S. (2001) Re-activation of an obliquely rifted margin, Campos and Santos Basins, southeastern Brazil. Am. Assoc. Pet. Geol. Bull., 85, 1925-1944.

Cobbold, P.R., Rossello, E.A., Roperch, P., Arriagada, C., Gómez, L.A. \& Lima, C. (2007) Distribution, timing, and causes of Andean deformation across South America. In: Deformation of the Continental Crust: The Legacy of Mike Comard (Ed. by Ries A.C., Butler R.W.H. \& Graham R.H.), Geological Society London Spec. Publ., 272, 583-592.

Cook, A.C. (ed.) (1982) The Origin and Petrology of Organic Matter in Coals, oil Shales and Petroleum Source Rocks, pp. 106. The University of Wollongong, Wollongong, NSW.

Dingle, R.V., Siesser, W.G. \& Newton, A.R. (1983) Mesozoic and Tertiary Geology of Southern Africa, pp. 375. A.A. Balkema, Rotterdam.

Duncan, R.A., Hooper, P.R., Rehacek, J., Marsh, J.S. \& DunCAN, R.A. (1997) The timing and duration of the Karoo igneous event, southern Gondwana. 7. Geophys. Res., 102, $18127-18138$.

Erlanger, E.D., Granger, D.E. \& Gibbon, R.J. (2012) Rock uplift rates in South Africa from isochron dating of fluvial and marine terraces. Geology, 40, 119-1022.

Galbraith, R.F. (2005) Statistics for Fission Track Analysis. Chapman and Hall/CRC, London.

Gallagher, K. \& Brown, R. (1999a) Denudation and uplift at passive margins: the record on the Atlantic Margin of Southern Africa. Philos. Trans. R. Soc. Lond., 357, 835-859.

Gallagher, K. \& Brown, R. (1999b) The Mesozoic denudation history of the Atlantic margins of southern Africa and southeast Brazil and the relationship to offshore sedimentation. In: The Oil and Gas Habitats of the South Atlantic (Ed. by Cameron N.R., Bate R.H. \& Clure V.S.), Geological Society of London Spec. Publ., 153, 412-453.

Gradstein, F.M., Ogg, J.G., Schmidtz, M.D. \& Ogg, G.M. (2012) A Geologic Time Scale 2012, Elsevier BV, Cambridge.

GREEN, P.F. (1986) On the thermo-tectonic evolution of Northern England: evidence from fission track analysis. Geol. Mag., 123, 493-506.

GreEn, P.F. \& Duddy, I. (2010) Synchronous exhumation events around the Arctic including examples from Barents Sea and Alaska North Slope. In: Petroleum Geology: From Mature Basins to New Frontiers - Proceedings of the 7th Petroleum Geology Conference (Ed. by B.A. Vining, S.C. Pickering), pp. 633-644. Geological Society, London.

GrEEN, P.F. \& DudDy, I.R. (2012) Thermal history reconstruction in sedimentary basins using apatite fission-track analysis and related techniques. In: Analyzing the Thermal History of Sedimentary Basins: Methods and Case Histories (Ed. by Harris N.D. \& Peters K.), SEPM Spec. Publ., 11, 65-104.

Green, P.F., Swart, R., Jacob, J., Ward, J. \& Bluck, B. (2009) Thermochronology and landscape development in Southern 
Africa. PESGB/HGS Africa Meeting (London), extended abstract.

Green, P.F., Japsen, P.J., Chalmers, J.A. \& Bonow, J.M. (2011) Erosion surfaces and missing section in West Greenland. 7. Geol. Soc., 168, 817-829.

Green, P.F., Lidmar-Bersgtröm, K., Japsen, P.J., Bonow, J.M. \& Chalmers, J.A. (2013) Stratigraphic landscape analysis, thermochronology and the episodic development of elevated, passive continental margins. Geol. Surv. Den. Greenl. Bull., 30, 150.

Gunnell, Y., Gallagher, K., Carter, A., Widdowson, M. \& Hurford, A.J. (2003) Denudation history of the continental margin of Peninsular India since the early Mesozoic - reconciling apatite fission-track data with geomorphology. Earth Planet. Sci. Lett., 67, 1-15.

Hanson, E.K., Moore, J.M., Bordy, E.M., Marsh, J.S., Howarth, G. \& Robey, J.V.A. (2009) Cretaceous erosion in central South Africa: evidence from crustal xenoliths in kimberlite diatremes. S. Afr. F. Geol., 112, 125-140.

Harman, R., Gallagher, K., Brown, R. \& Raza, A., Bizzi, L. (1998) Accelerated denudation and tectonic/geomorphic reactivation of the cratons of northeastern Brazil during the Late Cretaceous. F. Geophys. Res. Solid Earth, 103, 2709127105.

HiLl, R.S. (1992) Suurberg Group, Including the Slagboom, Coerney and Mimosa Formations. Volume 4. Catalogue of South African Lithostratigraphic Units. Council for Geoscience, Pretoria.

Houseman, G., McKenzie, D. \& Molnar, P. (1981) Convective instability of a thickened boundary layer and its relevance for thermal evolution of continental convergent belts. F. Geophys. Res., 86, 6115-6132.

Hurford, A.J. \& GREEN, P.F. (1983) The zeta age calibration of fission-track dating. Chem. Geol., 1, 285-317.

Japsen, P., Green, P.F. \& Chalmers, J.A. (2005) Separation of Palaeogene and Neogene uplift on Nuussuaq, West Greenland. 7. Geol. Soc. London, 162, 299-314.

Japsen, P., Bonow, J.M., Green, P.F., Chalmers, J.A. \& LiDMAR-BERGSTRÖM, K. (2006) Elevated passive continental margins: long-term highs or Neogene uplifts? New evidence from West Greenland. Earth Planet. Sci. Lett., 248, 315-324.

Japsen, P., Green, P.F., Bonow, J.M., Rasmussen, E.S., ChalMERS, J.A. \& KJENnERUd, T. (2010) Episodic uplift and exhumation along North Atlantic passive margins: implications for hydrocarbon prospectivity. In: Petroleum Geology: From Mature Basins to Nem Frontiers - Proceedings of the 7th Petroleum Geology Conference (Ed. by B.A. Vining, S.C. Pickering), pp. 979-1004. Geological Society, London.

Japsen, P., Chalmers, J.A., Green, P.F. \& Bonow, J.M. (2012a) Elevated passive continental margins: not rift shoulders but expressions of episodic post-rift burial and exhumation. Global Planet. Change, 90-91, 73-86.

Japsen, P., Bonow, J.M., Green, P.F., Cobbold, P.R., Chiossi, D., Lilletveit, R., Magnavita, L.P. \& Pedreira, A. (2012b) Episodic burial and exhumation in NE Brazil after opening of the South Atlantic. Bull. Geol. Soc. Am., 124, 800-816.

Japsen, P., Green, P.F., Bonow, J.M., Nielsen, T.F.D. \& Chalmers, J.A. (2014) From volcanic plains to glaciated peaks: burial and exhumation history of southern East Greenland after opening of the NE Atlantic. Global Planet. Change, $116,91-114$.

Jelsma, H.A., de Wit, M.J., Thiart, C., Dirks, P.H.G.M., Viola, G., Basson, I.J. \& AnCKar, E. (2004) Preferential dis- tribution along transcontinental corridors of kimberlites and related rocks of southern Africa. S. Afr. F. Geol., 107, 301324.

Jelsma, H., Barnett, W., Richards, S. \& Lister, G. (2009) Tectonic setting of kimberlites. Lithos, 112, 155-165.

Johnson, M.R., Anhaesseur, C.R. \& Thomas, R.J. (2009) The Geology of South Africa, pp. 691. Council for Geoscience, Pretoria.

Jourdan, F., Feraud, G., Bertrand, H., Kampunzu, A.B., Tshoso, G., Watkeys, M. \& Le Gall, B. (2005) Karoo large igneous province: brevity, origin and relation to mass extinction questioned by new ${ }^{40} \mathrm{Ar} /{ }^{39} \mathrm{Ar}$ data. Geology, 33, $745-748$

KEMPF, J. (2010) Morphotectonics and denudation in the landform history of the Namibian Great Escarpment landscapes. Z. Geomorph., 54, 347-376.

KING, L.C. (1951) South African Scenery, 2nd edn, pp. 379. Oliver and Boyd, Edinburgh.

KING, L.C. (1967) The Morphology of the Earth, 2nd edn. Oliver and Boyd, Edinburgh.

KING, L.C. (1972). The Natal Monocline: Explaining the Origin and Scenery of Natal, South Africa, 134 pp. Geology Department, University of Natal, Durban.

Kounov, A., Viola, G., De Wit, M. \& Andreoli, M.A.G. (2008) A Mid Cretaceous paleo-Karoo River valley across the Knersvlakte plain (northwestern coast of South Africa) from apatite fission-track analysis Evidence. S. Afr. F. Geol., 111, 409-420.

Kounov, A., Viola, G., De Wit, M. \& Andreoli, M.A.G. (2009) Denudation along the Atlantic passive margin: new insights from apatite fission-track analysis on the western coast of South Africa. In: Thermochronological Methods: From Palaeotemperature Constraints to Landscape Evolution Models (Ed. by Lisker F., Ventura B. \& Glasmacher U.A.), Geological Society, London Spec. Publ., 324, 287-306.

Kounov, A., Viola, G., Dunki, I. \& Frimmel, H.E. (2013) Southern African perspectives on the long-term morpho-tectonic evolution of cratonic interiors. Tectonophysics, 601, 177-191.

LEwIs, C.A. (1995) The Geomorphological Evolution of the Area Between Grahamstomn and the Indian Ocean, pp. 38. Rhodes University, Grahamstown.

Lithgow-Bertelloni, C. \& Silver, P. (1998) Dynamic topography, plate driving forces and the African superswell. Nature, 395, 269-272.

Macdonald, D., Gomez-Perez, I., Franzese, J., Spalletti, L., Lawver, L., Gahagan, L., Dalziel, I., Thomas, C., Trewin, N., Holoe, M. \& Paton, D. (2003) Mesozoic break-up of SW Gondwana: implications for regional hydrocarbon potential of the southern South Atlantic. Mar. Pet. Geol., 20, 287308.

Macdonald, J., Holford, S.P., Green., P.F., Duddy, I.R., KING, R.C. \& BACKE, G. (2013) Detrital zircon data reveal the origin of Australia's largest delta system. F. Geol. Soc., 170, 36.

MacGregor, D.S. (2012). Late Cretaceous-Cenozoic sediment and turbidite reservoir supply to South Atlantic margins. In: 2012. Conjugate Divergent Margins (Ed. by Mohriak W.U., Danforth A., Post P.J., Brown D.E., Tari G.C., Nemcok M. \& Sinha S.T.), Geological Society, London Spec. Publ., 369, doi:10.1144/SP369.7.

McMillan, I.K. (2003) Foraminiferally defined biostratigraphic episodes and sedimentation pattern of the Cretaceous drift succession (Early Barremian to late Maastrichtian) in seven 
basins on the South African and southern Namibian continental margin. S. Afr. F. Sci., 99, 537-576.

Molnar, P. \& England, P. (1990) Late Cenozoic uplift of mountain ranges and global climate change: chicken or egg? Nature, 346, 29-34.

Moore, A., Blenkinsop, T. \& Cotterill, F. (2008) Controls on post-Gondwana alkaline volcanism in southern Africa. Earth Planet. Sci. Lett., 268, 151-164.

Moore, A., Blenkinsop, T. \& Cotteril, F. (2009) Southern African topography and erosion history: plumes or tectonics? Terra Nova, 21, 310-315.

Newton, A.R., Shone, R.W. \& Booth, P.W.K. (2009) The cape fold belt. In: The Geology of South Africa (Ed. by M.R. Johnson, C.R. Anhaesseur \& R.J. Thomas), Chapter 24, pp. 521530. Council for Geoscience, Pretoria.

Ollier, C.D. \& Marker, M.E. (1985) The great escarpment of southern Africa. Z. Geomorph. Suppl., 54, 37-56.

OlLiER, C.D. \& PAIN, C.F. (1997) Equating the basal unconformity with the palaeoplain: a model for passive margins. Geomorphology, 19, 1-15.

Partridge, T.C. (1998) Of diamonds, dinosaurs and diastrophism: $150 \mathrm{Myr}$ if landscape evolution in southern Africa. S. Afr. F. Geol., 10, 167-184.

Partridge, T.C. \& Maud, R.R. (1987) Geomorphic evolution of southern Africa since the Mesozoic. S. Afr. F. Geol., 90, 179-208.

Paton, D.A. (2012) Post-rift deformation of the North East and South Atlantic margins: are passive margins really passive? In: Tectonics of Sedimentary Basins: Recent Advances (Ed. by C.A. Busby \& A. Azor), 647 pp. Blackwell Publishing Ltd, Chichester.

Paton, D.A. \& Underhill, J.R. (2004) Role of crustal anisotropy in modifying the structural and sedimentological evolution of extensional basins: the Gamtoos Basin, South Africa. Basin Res., 16, 339-359.

Paton, D.A., van der Spuy, D., di Primio, R. \& Horsfield, B. (2008) Tectonically induced adjustment of passive-margin accommodation space; influence on the hydrocarbon potential of the Orange Basin, South Africa. AAPG Bull., 92, 589-609.

Raab, M.J., Brown, R.W., Gallagher, K., Carter, A. \& WebBER, K. (2002) Late Cretaceous reactivation of major crustal shear zones in northern Namibia: constraints from apatite fission track analysis. Tectonophysics, 349, 75-92.

Raab, M.J., Brown, R.W., Gallagher, K., Webber, K. \& Gleadow, A.J.W. (2005) Denudational and thermal history of the Early Cretaceous Brandberg and Okenyenya igneous complexes on Namibia's passive margin. Tectonics, 24, TC3006.

RedField, T.F. (2010) On fission track dating and the Tertiary evolution of West Greenland topography. 7. Geol. Soc. London, 167, 261-271.

Roberts, G. \& White, N. (2010) Estimating uplift rate histories from river profiles using African examples. 7. Geophys. Res., 115, B02406.

Roberts, D.L., Viljoen, J.H.A., Macey, P., Nhleko, L., Cole, D.I., Chevallier, L., Gibson, L. \& Stapelberg, F. (2008)
The Geology of George and Environs. 1:50,000 map Sheet Explanation, pp. 76. Council for Geoscience, Pretoria.

Roberts, D.L., Botha, G.A., Maud, R.R. \& Pether, J. (2009) Coastal Cenozoic deposits. In: The Geology of South Africa (Ed. by M.R. Johnson, C.R. Anhaesseur \& R.J. Thomas), Chapter 29, pp. 585-604. Council for Geoscience, Pretoria.

Scharf, T., Codilean, A.T., de Wit, M., Jansen, J.D. \& KUBIK, P.W. (2013) Strong rocks sustain ancient post-orogenic topography in southern Africa. Geology, 41, 331-334.

SHone, R.W. (2009) Onshore post-Karoo Mesozoic deposits. In: The Geology of South Africa (Ed. by M.R. Johnson, C.R. Anhaesseur \& R.J. Thomas), Chapter 26, pp. 541-552. Council for Geoscience, Pretoria.

Simon, N.S.C. \& Podladchikov, Y.Y. (2008) The effect of mantle composition of density in the extending lithosphere. Earth Planet. Sci. Lett., 272, 148-157.

Sмiтh, R.M.H. (1986) Sedimentation and palaeoenvironments of Late Cretaceous crater-lake deposits in Bushmanland, South Africa. Sedimentology, 33, 369-386.

Stanley, J.R., Flowers, R.M. \& Bell, D.R. (2013) Kimberlite (U-Th)/He dating links surface erosion with lithospheric heating, thinning, and metasomatism in the southern African Plateau. Geology, 41, 1243-1246.

Stevenson, I.R. \& McMillan, I.K. (2004) Incised valley fill stratigraphy of the Upper Cretaceous succession, proximal Orange Basin, Atlantic margin of southern Africa. 7. Geol. Soc., 161, 185-208.

Svensen, H., Corfu, F., Polteau, S., Hammer, Ø. \& Planke, S. (2012) Rapid magma emplacement in the Karoo Large Igneous Province. Earth Planet. Sci. Lett., 325-326, 1-9.

Tankard, A., Welsink, H., Aukes, P., Newton, R. \& StetTLER, E. (2009) Tectonic evolution of the Cape and Karoo basins of South Africa. Mar. Pet. Geol., 26, 1379-1412.

Tinker, J., de Wit, M. \& Brown, R. (2008a) Mesozoic exhumation of the southern Cape, South Africa, quantified using apatite fission track thermochronology. Tectonophysics, 455, 77-93.

Tinker, J., de Wit, M. \& Brown, R. (2008b) Linking source and sink: evaluating the balance between onshore erosion and offshore sediment accumulation since Gondwana break-up, South Africa. Tectonophysics, 455, 94-103.

Turner, J.P., Green, P.F., Holford, S.P. \& Lawrence, S.R. (2008) Thermal history of the Rio Muni (West Africa)-NE Brazil margins during continental breakup. Earth Planet. Sci. Lett., 270, 354-367.

Viljoen, J.H.A., Stapelberg, F.D.J. \& Cloete, M. (2010) Technical Report on the Geological Storage of Carbon Dioxide in South Africa, pp. 238 Council for Geoscience, Pretoria.

de Wrt, M.J. (2007) The Kalahari Epeiorogeny and climate change: differentiating cause and effect from core to space. Inkaba ye Africa special volume. S. Afr. F. Geol., 110, 367392.

Manuscript received 10 Fuly 2014; In revised form 26 October 2015; Manuscript accepted 5 November 2015. 